\title{
Early transcriptomic response to Fe supply in Fe-deficient tomato plants is strongly influenced by the nature of the chelating agent
}

\author{
Anita Zamboni ${ }^{1}$, Laura Zanin² ${ }^{2}$ Nicola Tomasi ${ }^{2}$, Linda Avesani ${ }^{1}$, Roberto Pinton², Zeno Varanini ${ }^{1 *}$
} and Stefano $\mathrm{Cesco}^{3}$

\begin{abstract}
Background: It is well known that in the rhizosphere soluble Fe sources available for plants are mainly represented by a mixture of complexes between the micronutrient and organic ligands such as carboxylates and phytosiderophores (PS) released by roots, as well as fractions of humified organic matter. The use by roots of these three natural Fe sources (Fe-citrate, Fe-PS and Fe complexed to water-extractable humic substances, Fe-WEHS) have been already studied at physiological level but the knowledge about the transcriptomic aspects is still lacking.

Results: The ${ }^{59} \mathrm{Fe}$ concentration recorded after $24 \mathrm{~h}$ in tissues of tomato Fe-deficient plants supplied with ${ }^{59} \mathrm{Fe}$ complexed to WEHS reached values about 2 times higher than those measured in response to the supply with Fe-citrate and Fe-PS. However, after $1 \mathrm{~h}$ no differences among the three Fe-chelates were observed considering the ${ }^{59} \mathrm{Fe}$ concentration and the root Fe(III) reduction activity. A large-scale transcriptional analysis of root tissue after $1 \mathrm{~h}$ of Fe supply showed that Fe-WEHS modulated only two transcripts leaving the transcriptome substantially identical to Fe-deficient plants. On the other hand, Fe-citrate and Fe-PS affected 728 and 408 transcripts, respectively, having 289 a similar transcriptional behaviour in response to both Fe sources.

Conclusions: The root transcriptional response to the Fe supply depends on the nature of chelating agents (WEHS, citrate and PS). The supply of Fe-citrate and Fe-PS showed not only a fast back regulation of molecular mechanisms modulated by Fe deficiency but also specific responses due to the uptake of the chelating molecule. Plants fed with Fe-WEHS did not show relevant changes in the root transcriptome with respect to the Fe-deficient plants, indicating that roots did not sense the restored cellular Fe accumulation.
\end{abstract}

\section{Background}

Iron $(\mathrm{Fe})$ is the micronutrient required in the largest amount by plants and plays a role in key metabolic processes such as respiration, chlorophyll biosynthesis and photosynthesis. This element is a component of the heme group and Fe-sulphur clusters and other binding sites; for its chemical proprieties it is involved in many redox reactions but it can also favour the generation of reactive oxygen species (ROS), which implies a precise control of its uptake, utilization and storage [1].

\footnotetext{
* Correspondence: zeno.varanini@univr.it

${ }^{1}$ Department of Biotechnology, University of Verona, via delle Grazie 15,

37134 Verona, Italy

Full list of author information is available at the end of the article
}

To counteract the low availability of Fe in soils, higher plants have developed two different strategies for its acquisition from the rhizosphere. The Strategy I (all higher plants except grasses) relies on the improvement of Fe solubility through the release of root exudates like protons (via an increase of activity of plasma membrane $\mathrm{H}^{+}$-ATPase) and organic acids and phenolic compounds followed by a reduction of $\mathrm{Fe}(\mathrm{III})$ to the more soluble $\mathrm{Fe}(\mathrm{II})$ by a $\mathrm{Fe}(\mathrm{III})$ chelate reductase (FRO) [2]. This reductive step is essential for the acquisition of micronutrient, since $\mathrm{Fe}(\mathrm{II})$ is taken up via the activity of a divalent cation transporter, IronRegulated Transporter (IRT) [1]. Strategy II is specific for grasses and is based on the biosynthesis and release of phytosiderophores (PS), which have a strong affinity for Fe(III), 
and on the uptake of the Fe-PS complexes by a specific transporter, Yellow-Stripe (YS) [1].

Physiological and molecular responses to Fe deficiency in Strategy I species have been extensively studied in Arabidopsis thaliana [3]. In this model plant, a set of 92 transcripts responsive to Fe deficiency was identified [4]. In tomato roots, a similar number of transcripts (97) was modulated in response to Fe deficiency [5]. More recently, through a co-expression analysis, a group of 180 genes potentially involved in the regulation of Arabidopsis responses to Fe shortage was detected [6]. Several works describing plant transcriptional responses to Festress as a comparison between Fe sufficient and Fe deficient condition are present in literature [7-17]. However, no data are available on the modulations taking place during supply after a period of deficiency that is a condition reasonably occurring at the rhizosphere. In the recent years, this matter has been investigated at proteomic level in roots of Beta vulgaris [18] and in a Prunus hybrid [19], at metabolomic level in roots of Beta vulgaris [18], in the xylem sap and leaf extract of Strategy I plants [20].

In the rhizosphere the concentration of available $\mathrm{Fe}$ depends on the soil $\mathrm{pH}$ and on the presence of different types of natural ligands [2, 21-23], such as organic acids $[24,25]$, flavonoids [26, 27], PS [28], microbial siderophores [29] and fractions of the humified organic matter $[30,31]$. The acquisition mechanisms of Fe-chelates by Strategy I plants is considered to be based on the obligatory step of reduction [23], [32-34] even if recently their possibility to directly absorb Fe-PS has been envisaged [35]. Information about possible differences in the use efficiency of Fe-complexed to natural occurring chelates is still very scarce. It has been reported that fractions of low-molecular-weight water-extractable humic substances (WEHS) complexed with Fe(III) enhanced Fe deficiency responses when compared with natural (citrate) or synthetic [ethylenediaminetetraacetic acid (EDTA)] chelates [36]. Furthermore, a higher amount of ${ }^{59} \mathrm{Fe}$ was accumulated in tomato plants treated with Fe-WEHS after $24 \mathrm{~h}$ in comparison to other Fe sources [23]. The higher acquisition of Fe from Fe-WEHS was related to a more efficient reduction, rhizosphere acidification and translocation [22, 23, 37].

Here we describe the transcriptional responses of Fedeficient tomato roots after $1 \mathrm{~h}$ of supply with $1 \mu \mathrm{M}$ Fe chelated to citrate, PS or WEHS. Results showed that the root transcriptional profile of plants supplied with Fe-WEHS is very similar to that of Fe-deficient plants being only two transcripts differentially expressed. The other two natural sources of Fe caused on the other hand a similar modulation of a common set of 289 transcripts. In addition, the Fe-citrate and Fe-PS complexes showed some specific responses as suggested by the modulation of 439 and 119 transcripts after supplying Fe-citrate or Fe-PS alone, respectively.

\section{Results and discussion Iron- $\left({ }^{59} \mathrm{Fe}\right)$ accumulation from natural Fe-sources by tomato roots}

The capability of Fe-deficient tomato plants to utilize different natural Fe-sources was evaluated after 1, 4, or $24 \mathrm{~h}$ of treatment performing Fe-uptake experiments and using ${ }^{59} \mathrm{Fe}$ complexed with WEHS, citrate or PS. In order to reproduce conditions closer to those where Fedeficiency symptoms in crops usually appear [38], the uptake medium was buffered at $\mathrm{pH} 7.5$ and each $\mathrm{Fe}$ source was used at $1 \mu \mathrm{M}$ final Fe concentration.

Fig. 1a shows that after $1 \mathrm{~h}$ of supply, the concentration of ${ }^{59} \mathrm{Fe}$ accumulated in tomato plants was comparable among all the three Fe treatments exhibiting values around $100 \mathrm{nmol}{ }^{59} \mathrm{Fe} \mathrm{g}^{-1} \mathrm{DW}$ root. Iron content markedly increased up to four folds after $4 \mathrm{~h}$ and from six to 18 folds after $24 \mathrm{~h}$. In Fe-WEHS treated plants, the concentration of ${ }^{59} \mathrm{Fe}$ taken up was significantly greater than the one measured in plants treated with ${ }^{59} \mathrm{Fe}$-citrate or ${ }^{59} \mathrm{Fe}-\mathrm{PS}$ at 4 and $24 \mathrm{~h}$. Within each time point, there were no significant differences in Fe content in plants exposed to Fe-citrate and Fe-PS. Fe-sufficient plants (Fig. 1b) showed approximately one order of magnitude

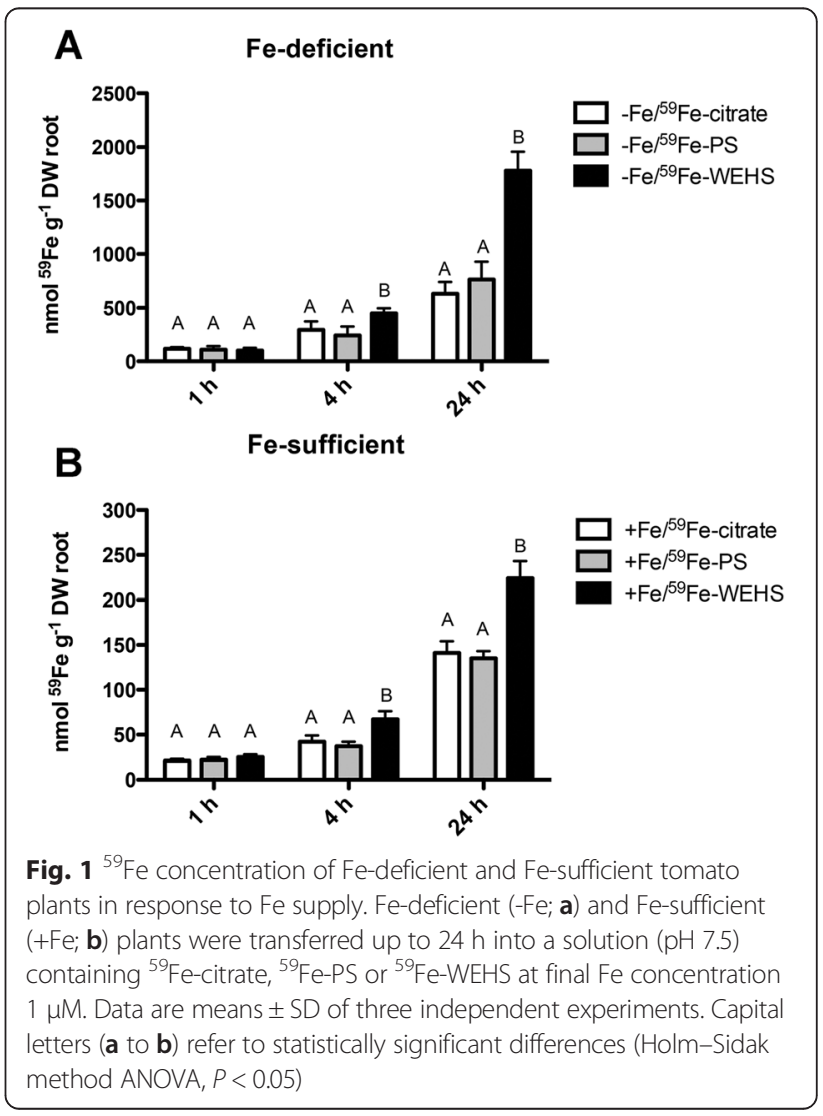


lower ${ }^{59} \mathrm{Fe}$ accumulation levels than Fe-deficient plants (Fig. 1a) suggesting that responses to Fe shortage are switched off. Also in this case Fe-WEHS treated plants accumulated the highest concentration of ${ }^{59} \mathrm{Fe}$ both at 4 and $24 \mathrm{~h}$.

In order to get information on the functionality of Feacquisition mechanisms working at the root level of plants supplied with different Fe-complexes, root $\mathrm{Fe}(\mathrm{III})$ reduction activity was measured after $1 \mathrm{~h}$ of treatment. Fig. 2 reports that the different type of Fe supply did not significantly modify the root Fe(III)-reduction activity.

\section{Changes in tomato root transcriptome in response to the supply with different natural Fe sources}

Root transcriptional profiles of tomato plants in response to $1 \mathrm{~h}$ supply with the three different Fe sources were characterized by a genome-wide microarray analysis.

Table 1 reports the numbers of upregulated and downregulated transcripts identified by Linear Models for MicroArray (LIMMA; adjusted p-value $\leq 0.05 ;\left|\log _{2}(\mathrm{R})\right| \geq 1$ ) [39] for each comparison of root transcriptional profiles. To have a further confirmation, the expression level of some differentially expressed transcripts was also tested by Realtime RT-PCR (Additional file 1: Table S1). The number of transcripts differentially expressed in response to Fe-citrate and Fe-PS supply was 728 and 408, respectively. Surprisingly, roots of tomato plants treated with Fe-WEHS showed only two differentially expressed transcripts (one upregulated and one downregulated) in comparison to the $\mathrm{Fe}$ deficiency condition (Table 2) indicating an elevated similarity between these two transcriptional profiles (Additional file 1: Figure S1). This behaviour might explain the higher ${ }^{59} \mathrm{Fe}$ content in Fe-WEHS-supplied tomato plants in comparison to Fe-citrate- and Fe-PS-supplied plants after 4 and $24 \mathrm{~h}$ (Fig. 1a).

The upregulated transcript in response to Fe-WEHSsupplied plants had the same behaviour in the plant

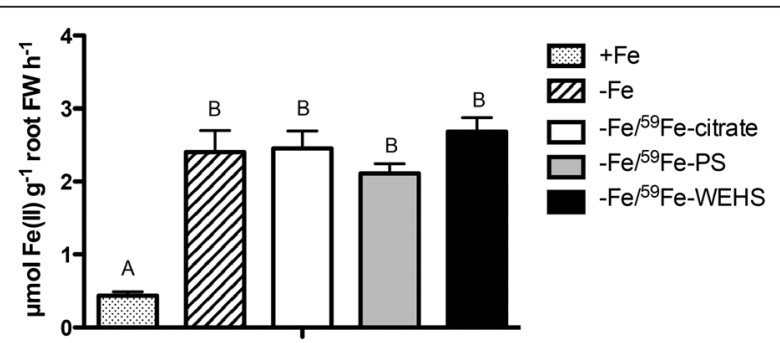

Fig. 2 Fe(III)-reduction activity of tomato roots. Fe(III)-reduction activity of intact Fe-deficient tomato plants supplied for $1 \mathrm{~h}$ with 1 MM Fe as Fe-citrate, Fe-PS or Fe-WEHS; as control, Fe-deficient plants not treated with any Fe sources (-Fe) or plants treated with $100 \mu \mathrm{M} F e(+F e)$, were also utilized. Data are means \pm SD of three independent experiments. Capital letters ( $a$ to $b$ ) refer to statistically significant differences (Holm-Sidak method ANOVA, $P<0.05$ )
Table 1 Number of differentially expressed transcripts resulted by transcriptional profile comparisons of Fe-deficient plants supplied with the three natural sources of Fe and Fe-deficient plants

\begin{tabular}{lll}
\hline Comparison & Upregulated transcript & Downregulated transcripts \\
\hline -Fe/Fe-citrate vs -Fe & 260 & 468 \\
-Fe/Fe-PS vs -Fe & 91 & 317 \\
-Fe/Fe-WEHS vs -Fe & 1 & 1 \\
\hline
\end{tabular}

Differentially expressed transcripts were identified by each transcriptional profile comparison through LIMMA analysis (adjusted $p$-value $\leq 0.05 ;\left|\log _{2}(R)\right| \geq 1$ ); - Fe: Fe-deficient; -Fe/Fe-citrate, -Fe/Fe-PS or -Fe/Fe-WEHS: Fe-deficient plants supplied for $1 \mathrm{~h}$ with Fe citrate, Fe-PS or Fe-WEHS, respectively

subjected to the other two treatments (Table 2 and Fig. 3). It encodes a R2R3 MYB transcription factor (\#1, Solyc06g005310.2.1; Table 2). The protein encoded by this tomato gene shows highest homology with Arabidopsis thaliana MYB48 (35\% of identity) that is not reported to be involved in responses to Fedeficiency in that plant species. Until now, in Strategy I plants, the regulation of Fe-deficiency responses has been described to be controlled by bHLH transcription factors $[1,40]$. Data here presented suggest that responses to Fe supply after a period of shortage could be driven by other transcription factors such as this MYB. The sole Fe-WEHS-specific transcript repressed encodes a putative amino acid transporter (\#2, Table 2) of unknown function. However, both transcriptional modulations seem unlikely to be responsible for the different efficient use of Fe as Fe-WEHS source.

The root transcriptional profiles of Fe-deficient plants supplied with the three natural sources compared to that of Fe-sufficient plants (LIMMA; adjusted $p$-value $\leq 0.05$; $\left|\log _{2}(R)\right| \geq 1$ ) showed that 90,1118 and 774 transcripts were after $1 \mathrm{~h}$ modulated in response to supply with Fe-WEHS, Fe-citrate and Fe-PS supplies respectively (Additional file 1: Table S2 and Figure S2, Additional file 2: Table S3). The number of differentially expressed transcripts between the Fe-WESH supplied plants and Fesufficient ones is similar (90 vs 97) to that identified in the previous transcriptional analysis comparing the transcriptome of Fe-sufficient and Fe-deficient roots [5]. It is therefore confirmed that the root transcriptional profile of Fe-deficient plants is very similar to that of plants supplied for $1 \mathrm{~h}$ with Fe-WEHS.

\section{Responses to Fe-citrate and Fe-PS treatments}

Differently from the transcriptional behaviour of FeWEHS, Fe-citrate and Fe-PS treatments vs Fe-deficient determined a modulation of a wider set of transcripts: 289 of them were in common, while 439 ( $60 \%$ of total differentially expressed transcripts of $-\mathrm{Fe} / \mathrm{Fe}$-citrate vs Fe-deficient comparison) and $119(\sim 30 \%$ of total differentially expressed transcripts of -Fe/Fe-PS vs Fe- 
Table 2 Differentially expressed transcripts cited in the Results and Discussion

\begin{tabular}{|c|c|c|c|c|c|c|c|c|}
\hline \# & Probe_ID & Description & $\begin{array}{l}\text { p-value, adj; } \\
\text {-Fe/Fe-citrate } \\
\text { vs -Fe }\end{array}$ & $\begin{array}{l}\log _{2}(\mathrm{R} ;-\mathrm{Fe} / \\
\text { Fe-citrate } \\
\text { vs -Fe }\end{array}$ & $\begin{array}{l}\text { p-value, adj; } \\
\text {-Fe/Fe-PS } \\
\text { vs -Fe }\end{array}$ & $\begin{array}{l}\log _{2}(\mathrm{R} ;- \\
\mathrm{Fe} / \mathrm{Fe}-\mathrm{PS} \\
\text { vs -Fe }\end{array}$ & $\begin{array}{l}\text { p-value, adj; } \\
\text {-Fe/Fe-WEHS } \\
\text { vs -Fe }\end{array}$ & $\begin{array}{l}\log _{2}\left(R_{;}-\right. \\
\text {Fe/Fe-WEHS } \\
\text { vs -Fe }\end{array}$ \\
\hline \multicolumn{9}{|c|}{$\begin{array}{l}\text { Transcripts similarly affected by Fe-citrate, Fe-PS } \\
\text { supply and Fe-WEHS }\end{array}$} \\
\hline \multirow[t]{2}{*}{$\# 1$} & TC215712_723_40_S & $\begin{array}{l}\text { R2R3-myb transcription } \\
\text { factor, putative }\end{array}$ & 0.001 & 2.20 & 0.001 & 2.14 & 0.035 & 2.02 \\
\hline & \multicolumn{8}{|c|}{ Transcripts affected by Fe-WEHS supply } \\
\hline \#2 & TC194872_1016_38_S & $\begin{array}{l}\text { Amino acid transporter, } \\
\text { putative }\end{array}$ & & & & & 0.035 & -1.74 \\
\hline \multicolumn{9}{|c|}{$\begin{array}{l}\text { Transcripts similarly affected } \\
\text { by Fe-citrate and Fe-PS supply }\end{array}$} \\
\hline \#3 & TC191891_2590_35_S & $\begin{array}{l}\text { Plasma membrane } \mathrm{H} \\
{ }^{+} \text {-ATPase }\end{array}$ & 0.003 & -1.72 & 0.010 & -1.41 & & \\
\hline$\# 4$ & TC202455_704_34_X2 & Fructokinase-2 & 0.006 & -1.39 & 0.008 & -1.47 & & \\
\hline \#5 & TC215677_337_34_X2 & $\begin{array}{l}\text { Fructose-bisphosphate } \\
\text { aldolase }\end{array}$ & 0.008 & -1.40 & 0.016 & -1.29 & & \\
\hline \#6 & TC203759_474_40_S & Succinate dehydrogenase & 0.001 & -1.67 & 0.003 & -1.40 & & \\
\hline \#7 & TC205577_582_35_S & $\begin{array}{l}\text { 2-Oxoglutarate } \\
\text { dehydrogenase, putative }\end{array}$ & 0.002 & -1.06 & 0.002 & -1.08 & & \\
\hline$\# 8$ & TC200117_1178_35_S & Methionine synthase & 0.004 & -1.94 & 0.009 & -1.72 & & \\
\hline$\# 9$ & TC211903_86_41_S & $\begin{array}{l}\text { SAM-dependent } \\
\text { methyltransferase }\end{array}$ & 0.003 & -1.40 & 0.013 & -1.09 & & \\
\hline$\# 10$ & TC212657_260_40_S & $\begin{array}{l}\text { SAM-dependent } \\
\text { methyltransferase }\end{array}$ & 0.011 & -1.10 & 0.020 & -1.06 & & \\
\hline \#11 & TC201480_474_36_S & $\begin{array}{l}\text { Phenylalanine ammonia- } \\
\text { lyase }\end{array}$ & 0.016 & -1.12 & 0.018 & -1.21 & & \\
\hline$\# 12$ & TC207536_637_35_S & $\begin{array}{l}\text { ABC transporter family } \\
\text { protein }\end{array}$ & 0.002 & -1.32 & 0.003 & -1.23 & & \\
\hline \#13 & TC192092_3871_40_S & Cellulose synthase & 0.002 & -1.34 & 0.001 & -1.60 & & \\
\hline \#14 & TC192418_1233_40_S & $\begin{array}{l}\text { Cellulose synthase catalytic } \\
\text { subunit }\end{array}$ & 0.002 & -1.72 & 0.003 & -1.54 & & \\
\hline \#15 & TC214973_590_40_S & $\begin{array}{l}\text { Cellulose synthase A catalytic } \\
\text { subunit } 3\end{array}$ & 0.004 & -1.11 & 0.004 & -1.23 & & \\
\hline \#16 & TC204385_218_36_X2 & UDP-apiose/xylose synthase & 0.003 & -1.69 & 0.026 & -1.11 & & \\
\hline \#17 & TC192860_1143_39_S & Expansin 1 protein & 0.017 & 1.28 & 0.026 & 1.26 & & \\
\hline \#18 & TC198812_683_37_S & $\begin{array}{l}\text { Glucan endo-1,3-beta-gluco- } \\
\text { sidase, putative }\end{array}$ & 0.017 & 1.05 & 0.010 & 1.31 & & \\
\hline \#19 & TC201525_569_35_S & $\begin{array}{l}\text { Rho GTPase-activating pro- } \\
\text { tein At5g61530 }\end{array}$ & 0.002 & -1.43 & 0.003 & -1.34 & & \\
\hline$\# 20$ & TC196357_464_36_S & $\begin{array}{l}\text { ATP/GTP/Ca }{ }^{++} \text {binding } \\
\text { protein }\end{array}$ & 0.006 & -1.60 & 0.022 & -1.29 & & \\
\hline$\# 21$ & TC211495_432_40_S & $\begin{array}{l}\text { CBL-interacting protein kinase } \\
1\end{array}$ & 0.004 & -1.18 & 0.003 & -1.45 & & \\
\hline \#22 & TC212764_568_34_X2 & Protein IQ-DOMAIN 14 & 0.003 & -1.35 & 0.008 & -1.20 & & \\
\hline \#23 & TC197849_292_41_X2 & $\begin{array}{l}\text { Ras-related GTP binding } \\
\text { protein }\end{array}$ & 0.016 & -1.01 & 0.017 & -1.10 & & \\
\hline \#24 & TC207137_449_35_S & $\begin{array}{l}\text { RAS superfamily GTP-binding } \\
\text { protein-like }\end{array}$ & 0.002 & -1.38 & 0.007 & -1.07 & & \\
\hline$\# 25$ & TC196878_2001_40_S & Malic enzyme & 0.010 & -1.20 & 0.013 & -1.25 & & \\
\hline$\# 26$ & TC191720_1243_40_S & $\begin{array}{l}\text { NADH:ubiquinone } \\
\text { oxidoreductase-like }\end{array}$ & 0.012 & 1.29 & 0.027 & 1.17 & & \\
\hline
\end{tabular}


Table 2 Differentially expressed transcripts cited in the Results and Discussion (Continued)

\begin{tabular}{|c|c|c|c|c|c|c|}
\hline \#27 & TC210154_386_41_X4 & Glutamate dehydrogenase & 0.005 & -1.45 & 0.016 & -1.23 \\
\hline \#28 & TC192029_938_40_S & $\begin{array}{l}\text { Putative basic helix-loop- } \\
\text { helix protein bHLH7 }\end{array}$ & 0.005 & 1.17 & 0.007 & 1.23 \\
\hline \multicolumn{7}{|c|}{$\begin{array}{l}\text { Transcript specifically affected } \\
\text { by Fe-citrate supply }\end{array}$} \\
\hline$\# 29$ & TC208592_1291_35_S & $\begin{array}{l}\text { Triosephosphate isomerase, } \\
\text { chloroplastic (TIM) }\end{array}$ & 0.004 & -1.27 & & \\
\hline \#30 & TC194624_64_34_S & $\begin{array}{l}\text { 6-Phosphogluconate } \\
\text { dehydrogenase }\end{array}$ & 0.002 & -1.20 & & \\
\hline \#31 & TC199057_182_40_S & $\begin{array}{l}\text { Putative pyruvate } \\
\text { dehydrogenase E1 beta } \\
\text { subunit }\end{array}$ & 0.036 & -1.15 & & \\
\hline \#32 & TC201985_646_40_S & Citrate synthase & 0.001 & -1.39 & & \\
\hline \#33 & TC212309_491_35_S & $\begin{array}{l}\text { Phosphoenolpyruvate } \\
\text { carboxylase }\end{array}$ & 0.048 & -1.03 & & \\
\hline \#34 & TC193693_30_35_S & $\begin{array}{l}\text { NADH dehydrogenase, } \\
\text { putative }\end{array}$ & 0.003 & -1.21 & & \\
\hline \#35 & TC195215_205_34_X2 & $\begin{array}{l}\text { NADH dehydrogenase, } \\
\text { putative }\end{array}$ & 0.003 & -1.41 & & \\
\hline \#36 & TC193283_737_36_S & PHB2 & 0.001 & -1.19 & & \\
\hline \#37 & TC212977_600_37_S & Nitrite reductase & 0.049 & 1.12 & & \\
\hline \#38 & TC196100_60_35_S & $\begin{array}{l}\text { Plastid glutamine synthetase } \\
\text { GS2 }\end{array}$ & 0.004 & -1.17 & & \\
\hline \#39 & TC211800_873_40_S & $\begin{array}{l}\text { Putative ferredoxin- } \\
\text { dependent glutamate syn- } \\
\text { thase } 1\end{array}$ & 0.006 & -1.00 & & \\
\hline$\# 40$ & TC197827_1154_40_S & Leucine-rich repeat/extensin & 0.030 & -1.13 & & \\
\hline \#41 & TC203111_299_41_X2 & Extensin-like protein & 0.001 & -1.34 & & \\
\hline \#42 & TC204863_245_40_S & Extensin-like protein Ext1 & 0.016 & -1.15 & & \\
\hline \#43 & TC216971_395_35_S & Extensin class 1 protein & 0.030 & 1.10 & & \\
\hline \#44 & TC196973_752_38_X2 & Pectinesterase & 0.019 & 1.11 & & \\
\hline \#45 & TC210207_490_35_S & Pectinesterase & 0.004 & -1.18 & & \\
\hline \#46 & TC193792_675_36_S & $\begin{array}{l}\text { Putative glutathione S- } \\
\text { transferase T5 }\end{array}$ & 0.023 & 1.48 & & \\
\hline \#47 & TC202880_782_35_S & Glutathione S-transferase & 0.003 & -1.05 & & \\
\hline \#48 & TC207401_351_40_S & $\begin{array}{l}\text { Glutathione S-transferase/ } \\
\text { peroxidase }\end{array}$ & 0.029 & 1.17 & & \\
\hline \#49 & TC211832_300_41_X2 & $\begin{array}{l}\text { Glutathione-regulated } \\
\text { potassium-efflux system pro- } \\
\text { tein kefB, putative }\end{array}$ & 0.034 & 1.09 & & \\
\hline \#50 & TC197773_1109_35_S & Peroxidase & 0.032 & 1.08 & & \\
\hline \#51 & TC209710_467_35_S & Peroxidase 16 , putative & 0.012 & -1.17 & & \\
\hline \#52 & TC192043_591_40_X3 & $\begin{array}{l}17.6 \mathrm{kDa} \text { class I heat shock } \\
\text { protein (Hsp20.0) }\end{array}$ & 0.044 & 1.03 & & \\
\hline \#53 & TC194246_668_40_S & $\begin{array}{l}\text { Heat shock protein } 70 \\
\text { (HSP70) }\end{array}$ & 0.002 & -1.00 & & \\
\hline \#54 & TC197122_92_35_S & $\begin{array}{l}\text { Hsp90 co-chaperone AHA1, } \\
\text { putative }\end{array}$ & 0.002 & -1.24 & & \\
\hline \#55 & TC207719_568_36_S & $\begin{array}{l}\text { Chaperone protein DNAj, } \\
\text { putative }\end{array}$ & 0.036 & 1.06 & & \\
\hline \#56 & TC208736_54_40_S & Chaperonin-60 alpha subunit & 0.044 & 1.05 & & \\
\hline
\end{tabular}


Table 2 Differentially expressed transcripts cited in the Results and Discussion (Continued)

\begin{tabular}{|c|c|c|c|c|c|c|}
\hline$\# 57$ & TC214617_585_34_X2 & Hsp70-interacting protein 1 & 0.002 & -1.17 & & \\
\hline \#58 & TC195735_752_37_S & $\begin{array}{l}\text { Avr } 9 / \text { Cf-9 rapidly elicited } \\
\text { protein }\end{array}$ & 0.045 & 1.98 & & \\
\hline \#59 & TC196669_798_35_S & $\begin{array}{l}\text { Avr } 9 / C f-9 \text { rapidly elicited } \\
\text { protein } 1\end{array}$ & 0.040 & 2.57 & & \\
\hline \#60 & TC198633_775_40_S & $\begin{array}{l}\text { Avr9/Cf-9 rapidly elicited } \\
\text { protein } 231\end{array}$ & 0.019 & 1.94 & & \\
\hline$\# 61$ & TC200277_609_40_S & $\begin{array}{l}\text { Avr9/Cf-9 rapidly elicited } \\
\text { protein } 194\end{array}$ & 0.032 & 1.81 & & \\
\hline \#62 & TC203605_414_40_S & $\begin{array}{l}\text { Avr } 9 / \text { Cf- } 9 \text { rapidly elicited } \\
\text { protein } 75\end{array}$ & 0.037 & 1.59 & & \\
\hline \#63 & TC204489_664_34_X2 & $\begin{array}{l}\text { Avr9/Cf-9 rapidly elicited } \\
\text { protein } 20\end{array}$ & 0.008 & 2.15 & & \\
\hline \#64 & TC207986_456_38_S & $\begin{array}{l}\text { Avr9/Cf-9 rapidly elicited } \\
\text { protein } 231\end{array}$ & 0.006 & 3.69 & & \\
\hline \#65 & TC208735_320_38_S & $\begin{array}{l}\text { Avr9/Cf-9 rapidly elicited } \\
\text { protein } 65\end{array}$ & 0.006 & 3.28 & & \\
\hline \#66 & TC200524_503_40_S & $\begin{array}{l}\text { WRKY-type DNA binding } \\
\text { protein }\end{array}$ & 0.035 & 1.48 & & \\
\hline \#67 & TC201566_1542_35_S & WRKY-like transcription factor & 0.040 & 1.68 & & \\
\hline \#68 & TC205993_1465_40_S & WRKY transcription factor 1 & 0.023 & 2.50 & & \\
\hline \#69 & TC209196_761_40_S & $\begin{array}{l}\text { Double WRKY type } \\
\text { transfactor }\end{array}$ & 0.014 & 1.87 & & \\
\hline \#70 & TC214887_802_40_S & WRKY transcription factor-30 & 0.006 & 1.20 & & \\
\hline \#71 & TC191592_2431_37_S & GRAS6 & 0.006 & 1.09 & & \\
\hline \#72 & TC192009_1993_40_S & GRAS1 & 0.038 & 1.14 & & \\
\hline \#73 & TC192616_2450_39_S & $\begin{array}{l}\text { GRAS family transcription } \\
\text { factor }\end{array}$ & 0.018 & 1.37 & & \\
\hline \#74 & TC193990_2097_35_S & GRAS9 & 0.029 & 1.20 & & \\
\hline \#75 & TC195584_1695_40_S & GRAS4 & 0.023 & 1.28 & & \\
\hline \#76 & TC208078_576_35_S & GRAS4 & 0.007 & 2.01 & & \\
\hline \multirow[t]{2}{*}{$\# 77$} & TC213462_831_40_S & GRAS2 transcription factor & 0.034 & 1.93 & & \\
\hline & \multicolumn{6}{|c|}{ Transcript specifically affected by Fe-PS supply } \\
\hline \#78 & TC197535_663_40_S & $\begin{array}{l}\text { 3-Hydroxyacyl-CoA } \\
\text { dehyrogenase }\end{array}$ & & & 0.004 & -1.21 \\
\hline \#79 & TC203351_729_35_S & $\begin{array}{l}\text { Fatty acid desaturase, } \\
\text { putative }\end{array}$ & & & 0.004 & -1.08 \\
\hline \#80 & TC201677_436_40_S & Acyl-CoA synthetase & & & 0.002 & -1.33 \\
\hline \#81 & TC195028_1952_40_S & Putative phospholipase $C$ & & & 0.026 & -1.12 \\
\hline \#82 & TC196917_1568_38_S & Delta(14)-sterol reductase & & & 0.026 & 1.02 \\
\hline \#83 & TC215747_470_40_S & $\begin{array}{l}\text { Phosphatidic acid } \\
\text { phosphatase }\end{array}$ & & & 0.041 & -1.00 \\
\hline \#84 & TC195925_676_35_X2 & Ascorbate oxidase & & & 0.049 & -1.03 \\
\hline \#85 & TC211305_518_35_S & $\begin{array}{l}\text { Oligopeptide transporter, } \\
\text { putative }\end{array}$ & & & 0.044 & -1.06 \\
\hline \#86 & TC196465_645_40_X2 & $\begin{array}{l}\text { Gibberellin } 20 \text { oxidase, } \\
\text { putative }\end{array}$ & & & 0.029 & -1.03 \\
\hline \#87 & TC204594_438_40_S & TGA10 transcription factor & & & 0.014 & -1.26 \\
\hline \#88 & TC196692_694_37_X2 & GRAS1 & & & 0.041 & -1.18 \\
\hline \#89 & TC211460_599_40_S & & & & 0.014 & -1.01 \\
\hline
\end{tabular}


Table 2 Differentially expressed transcripts cited in the Results and Discussion (Continued)

\begin{tabular}{lllll}
\hline \multicolumn{1}{c}{ bHLH transcription factor } & & \\
& JAF13 & & \\
\#90 TC214149_2_40_S & Myb-like protein & 0.029 & 1.07 \\
\#91 TC204269_546_39_S & $\begin{array}{l}\text { Homeobox-leucine zipper } \\
\text { protein ATHB-52 }\end{array}$ & 0.007 & 1.12 \\
\hline
\end{tabular}

Probe ID, description, adjusted $p$-value and $\log _{2}(\mathrm{R})$ were reported for each comparison

deficient) transcripts were Fe-citrate- and Fe-PS-specific, respectively (Fig. 3). These transcripts are related to specific responses that could be caused by the effect of different chelating agents on root plant metabolism. This hypothesis could be supported by the results obtained comparing the transcriptional profiles of Fe-deficient plant roots supplied for $1 \mathrm{~h}$ with $\mathrm{Fe}$ (Fe-citrate and $\mathrm{Fe}-\mathrm{PS}$ ) with Fe-sufficient plants (Additional file 1: Figure S2). This analysis revealed that about $52 \%$ and $30 \%$ of differentially expressed transcripts were specific for the $-\mathrm{Fe} / \mathrm{Fe}$-citrate vs Fe-sufficient and -Fe/Fe-PS vs Fe-sufficient comparisons, respectively (Additional file 1: Table S2, Figure S2).

Differentially expressed transcripts in the comparisons - Fe/Fe-citrate vs Fe-deficient and -Fe/Fe-PS vs Fedeficient (Table 1), were manually annotated using terms of the biological process of the Gene Ontology (GO) [41] on the basis of BlastP analysis from UniProt database [42] (Additional file 3: Table S4). Eighty-five $(11.67 \%)$ and 64 (15.69 \%) differentially expressed transcripts in response to Fe-citrate and Fe-PS treatment, respectively, encode proteins without homology with

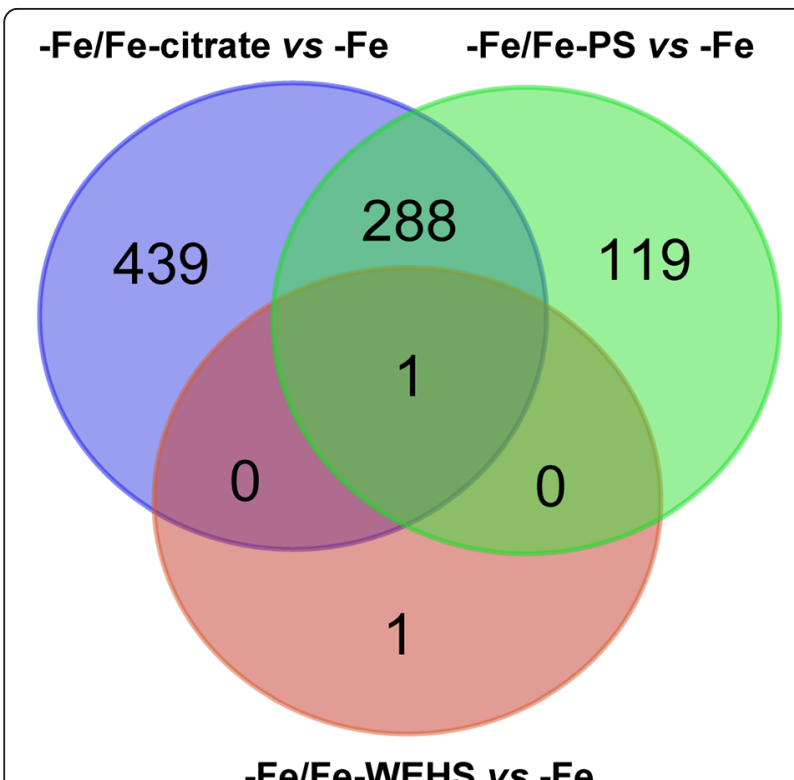

-Fe/Fe-WEHS vs -Fe

Fig. 3 Shared transcripts modulated in response to supply with the three natural Fe sources relative to Fe-deficient plants. Fe-deficient plants were supplied for $1 \mathrm{~h}$ with Fe-WEHS (-Fe/Fe-WEHS) or with Fe-PS (-Fe/Fe-PS) or with Fe-citrate (-Fe/Fe-citrate). As control, Fedeficient plants were used (-Fe) known proteins ("no hits found"). Table 3 shows that "biological process" (transcripts encoding protein involved in "unknown" biological process), "cellular process" and "metabolic process" are the more represented functional categories with similar percentage both for responses to Fe-citrate and Fe-PS supply. The other GO term categories showed similar percentages between the two treatments with the exceptions of "cellular component organization and biogenesis" that is more represented in the response to Fe-citrate relative to Fe-PS (3.53\% vs $1.77 \%)$ while "lipid metabolic process" in the response to Fe-PS relative to Fe-citrate ( $2.00 \%$ vs $0.92 \%)$.

\section{Transcripts commonly modulated by Fe-citrate and Fe-PS supply}

The 289 transcripts commonly modulated after Fecitrate and Fe-PS supply showed the same trend (235 downregulated and 54 upregulated transcripts, Additional file 3: Table S4). Excluding the peculiar behaviour of transcriptome in the presence of Fe-WEHS, this set of transcripts seems to represent the part of transcriptome responsive to the Fe-supply. Twenty upregulated transcripts and thirteen downregulated transcripts did not show any sequence homology with known proteins ("no hits found"). The distribution analysis of the main functional categories of transcripts with homology to known proteins showed that the more abundant terms "biological process", "cellular process", "metabolic process" and "biosynthetic process" were similarly represented in both downregulated and upregulated set of transcripts (Table 4). Differences were observed for "transport" with a higher fraction of a downregulated transcript dataset relative to the upregulated one (3.66 \% vs $1.22 \%)$ while other categories such as "carbohydrate metabolic process", "catabolic process", "cellular component organization and biogenesis" and "photosynthesis" were less represented in the downregulated transcript dataset (Table 4).

The downregulation of a plasma membrane $\mathrm{H}^{+}$-ATPase transcript (\#3, Table 2) suggested that the acidification of the rhizosphere (component of Fe-acquisition machinery) is more quickly modulated than the expression of transcripts encoding FRO and IRT.

Comparing the modulation of these common supply-specific transcripts with the results of the previous findings in tomato roots [5], we could observe that with the exception of transcripts related to $\mathrm{Fe}$ 
Table 3 Distribution in main functional categories of transcripts differentially expressed in response to Fe-citrate and Fe-PS supply respectively

\begin{tabular}{|c|c|c|c|c|c|c|c|}
\hline \multicolumn{4}{|c|}{-Fe/Fe-citrate vs -Fe } & \multicolumn{4}{|c|}{-Fe/Fe-PS vs -Fe } \\
\hline GO Class ID & Definitions & Counts & Fractions & GO Class ID & Definitions & Counts & Fractions \\
\hline GO:0008150 & biological_process & 178 & $27.34 \%$ & GO:0008150 & biological_process & 122 & $27.05 \%$ \\
\hline GO:0009987 & cellular process & 118 & $18.13 \%$ & GO:0009987 & cellular process & 80 & $17.74 \%$ \\
\hline GO:0008152 & metabolic process & 101 & $15.51 \%$ & GO:0008152 & metabolic process & 76 & $16.85 \%$ \\
\hline GO:0009058 & biosynthetic process & 33 & $5.07 \%$ & GO:0009058 & biosynthetic process & 27 & $5.99 \%$ \\
\hline GO:0006139 & $\begin{array}{l}\text { nucleobase, nucleoside, } \\
\text { nucleotide and nucleic } \\
\text { acid metabolic process }\end{array}$ & 24 & $3.69 \%$ & GO:0006139 & $\begin{array}{l}\text { nucleobase, nucleoside, nucleotide } \\
\text { and nucleic acid metabolic process }\end{array}$ & 18 & $3.99 \%$ \\
\hline GO:0016043 & $\begin{array}{l}\text { cellular component } \\
\text { organization and biogenesis }\end{array}$ & 23 & $3.53 \%$ & GO:0019538 & protein metabolic process & 16 & $3.55 \%$ \\
\hline GO:0019538 & protein metabolic process & 22 & $3.38 \%$ & GO:0006810 & transport & 13 & $2.88 \%$ \\
\hline GO:0006810 & transport & 20 & $3.07 \%$ & GO:0005975 & carbohydrate metabolic process & 11 & $2.44 \%$ \\
\hline GO:0009056 & catabolic process & 17 & $2.61 \%$ & GO:0009056 & catabolic process & 11 & $2.44 \%$ \\
\hline GO:0005975 & $\begin{array}{l}\text { carbohydrate metabolic } \\
\text { process }\end{array}$ & 13 & $2.00 \%$ & GO:0006629 & lipid metabolic process & 9 & $2.00 \%$ \\
\hline GO:0006950 & response to stress & 12 & $1.84 \%$ & GO:0016043 & $\begin{array}{l}\text { cellular component organization } \\
\text { and biogenesis }\end{array}$ & 8 & $1.77 \%$ \\
\hline GO:0007154 & cell communication & 9 & $1.38 \%$ & GO:0007165 & signal transduction & 6 & $1.33 \%$ \\
\hline GO:0006091 & $\begin{array}{l}\text { generation of precursor metabolites and } \\
\text { energy }\end{array}$ & 9 & $1.38 \%$ & GO:0007154 & cell communication & 6 & $1.33 \%$ \\
\hline GO:0007165 & signal transduction & 8 & $1.23 \%$ & GO:0006950 & response to stress & 6 & $1.33 \%$ \\
\hline GO:0006464 & protein modification process & 8 & $1.23 \%$ & GO:0006464 & protein modification process & 6 & $1.33 \%$ \\
\hline GO:0006259 & DNA metabolic process & 6 & $0.92 \%$ & GO:0006091 & $\begin{array}{l}\text { generation of precursor metabolites } \\
\text { and energy }\end{array}$ & 5 & $1.11 \%$ \\
\hline GO:0006629 & lipid metabolic process & 6 & $0.92 \%$ & GO:0006259 & DNA metabolic process & 4 & $0.89 \%$ \\
\hline GO:0009628 & response to abiotic stimulus & 5 & $0.77 \%$ & GO:0006412 & translation & 4 & $0.89 \%$ \\
\hline GO:0009719 & response to endogenous stimulus & 5 & $0.77 \%$ & GO:0015979 & photosynthesis & 3 & $0.67 \%$ \\
\hline GO:0006412 & translation & 5 & $0.77 \%$ & GO:0016265 & death & 2 & $0.44 \%$ \\
\hline GO:0015979 & photosynthesis & 4 & $0.61 \%$ & GO:0009628 & response to abiotic stimulus & 2 & $0.44 \%$ \\
\hline GO:0016265 & death & 3 & $0.46 \%$ & GO:0009607 & response to biotic stimulus & 2 & $0.44 \%$ \\
\hline GO:0008219 & cell death & 3 & $0.46 \%$ & GO:0009719 & response to endogenous stimulus & 2 & $0.44 \%$ \\
\hline GO:0000003 & reproduction & 2 & $0.31 \%$ & GO:0008219 & cell death & 2 & $0.44 \%$ \\
\hline GO:0009607 & response to biotic stimulus & 2 & $0.31 \%$ & GO:0040007 & growth & 2 & $0.44 \%$ \\
\hline GO:0007275 & multicellular organismal development & 2 & $0.31 \%$ & GO:0000003 & reproduction & 1 & $0.22 \%$ \\
\hline GO:0040007 & growth & 2 & $0.31 \%$ & GO:0009791 & post-embryonic development & 1 & $0.22 \%$ \\
\hline GO:0007049 & cell cycle & 2 & $0.31 \%$ & GO:0009605 & response to external stimulus & 1 & $0.22 \%$ \\
\hline GO:0009791 & post-embryonic development & 1 & $0.15 \%$ & GO:0009908 & flower development & 1 & $0.22 \%$ \\
\hline GO:0009653 & anatomical structure morphogenesis & 1 & $0.15 \%$ & GO:0007275 & $\begin{array}{l}\text { multicellular organismal } \\
\text { development }\end{array}$ & 1 & $0.22 \%$ \\
\hline GO:0009605 & response to external stimulus & 1 & $0.15 \%$ & GO:0016049 & cell growth & 1 & $0.22 \%$ \\
\hline GO:0009908 & flower development & 1 & $0.15 \%$ & GO:0019725 & cell homeostasis & 1 & $0.22 \%$ \\
\hline GO:0019748 & secondary metabolic process & 1 & $0.15 \%$ & GO:0007049 & cell cycle & 1 & $0.22 \%$ \\
\hline
\end{tabular}


Table 3 Distribution in main functional categories of transcripts differentially expressed in response to Fe-citrate and Fe-PS supply respectively (Continued)

\begin{tabular}{|c|c|c|c|c|c|c|}
\hline GO:0016049 & cell growth & 1 & $0.15 \%$ & Total & 451 & $100.00 \%$ \\
\hline GO:0009875 & pollen-pistil interaction & 1 & $0.15 \%$ & & & \\
\hline GO:0019725 & cell homeostasis & 1 & $0.15 \%$ & & & \\
\hline GO:0009856 & pollination & 1 & $0.15 \%$ & & & \\
\hline Total & & 651 & $100.00 \%$ & & & \\
\hline
\end{tabular}

The distribution in main functional categories on the basis of "biological process" terms was performed using CateGOrizer [79] setting Plant GO slim method and consolidated single occurrences. The analysis was performed using the GO terms of the 643 and 344 transcripts differentially expressed in response to Fe-citrate and Fe-PS respectively and showing homology to "known protein"

homeostasis (e.g. those encoding FRO, IRT and Natural Resistance-Associated Macrophage Protein, NRAMP) most of the molecular mechanisms involved in the response to the Fe shortage (e.g. glycolysis, TCA cycle, methionine cycles, protein turnover, phenolic compound biosynthesis, root morphological adaptation and signalling) were modulated suggesting the restoration of sufficient nutrient condition. Specifically, we detected a negative modulation of transcripts encoding a phosphofructokinase (PFK; \#4), a fructose-bisphosphate aldolase (FBP; \#5) for glycolysis and a succinate dehydrogenase (SDH; \#6) and a 2'-oxaglutarate dehydrogenase (OGDC; \#7) for tri-carboxylic acid (TCA) cycle (Table 2). As far as methionine metabolism and cycle is concerned a methionine synthase (MS; \#8) and two S-adenosylmethioninedependent methyltransferase (SAMT) transcripts (\#9 and \#10) were repressed (Table 2). Furthermore, transcripts involved in protein turnover such as proteases and peptidases (Additional file 3: Table S4) were mainly negatively affected suggesting the readjusting of the protein metabolism related to the anaplerotic functions. The synthesis and transport of phenolic secondary metabolites appear to be negatively affected as highlighted by the downregulation of transcripts encoding a phenylalanine ammonia-lyase (PAL, $\# 11)$ and an ATP-binding cassette (ABC) transporter [43] (\#12, Table 2). A similar behaviour was observed for transcripts involved in the synthesis of cell wall components (cellulose synthases, CES, \#13, \#14 and \#15 and UDPapiose/xylose synthase, AXS, \#16) while cell wall loosening and modification appeared to be positively influenced by the presence of the micronutrient as highlighted by the upregulation of transcripts encoding an expansin (LeExp1, $\# 17$, Table 2) and a glucan endo-1,3-beta-glucosidase (\#18, Table 2) [44-47]. Concerning the role of $\mathrm{Ca}^{2+}$ as secondary messenger during Fe shortage, the negative modulation of signal transduction machinery genes (Rho GTPaseactivating protein 1 , \#19; ATP/GTP/Ca ${ }^{++}$binding protein, \#20; mitochondrial Rho GTPase calcineurin B-like (CBL)interacting protein kinase 1, \#21; Protein IQ-DOMAIN 14, \#22; Ras-related GTP binding protein, \#23 and \#24) is in agreement with the adjustment due to the restored nutrient conditions (Table 2).
Together with the general behaviour described above suggesting the readjustment of metabolic pathways linked to Fe shortage to an adequate nutritional condition, our analysis revealed that other mechanisms are involved in this response.

It is known that the alternative pathway of pyruvate synthesis independent of pyruvate kinase (PK), which is involved in the supply of low-molecular weight organic acid to TCA cycle, is induced under Fe-deficiency [48]; this behaviour would allow to supply reducing power in plants where the functionality of the mitochondrial respiratory chain is limited $[49,50]$. A malic enzyme (ME) transcript (\#25, Table 2) was repressed in response to Fe supply, hence decreasing the substrate provision to the alternative metabolic cycle. Furthermore, the overexpression of the subunit I of the NADH:ubiquinone oxidoreductase transcript (NADH_UbQ_OxRdtase; \#26, Table 2) suggests that Fe supply could restore the respiration chain activity. The repression of a transcript encoding a glutamate dehydrogenase (GDH; \#27, Table 2) related to anaplerotic reaction of TCA [51] reinforces the hypothesis of a possible back regulation of TCA cycle during the supply.

Focusing on the transcript involved in molecular processes leading to protein synthesis (i.e. translation GO:000641), protein folding (GO:0006457) and protein modification (i.e. protein phosphorylation GO:0006468, protein dephosphorylation GO:0006470; protein glycosylation GO:0006486) we observed a downregulation rather than an upregulation (Table 4). This suggests that the new protein synthesis and/or protein modification [52] necessary to respond to the micronutrient depletion are not required in the new restored nutrient condition. We also recorded a downregulation of transcripts involved in DNA and RNA metabolic processes (i.e. DNA topological changes GO:0006265; DNA replication initiation GO:0006270; DNA repair GO:0006281; transcription, DNA-templated GO:0006351; regulation of transcription, DNA-templated GO:0006355; RNA splicing GO:0008380) that could be in line with the decrease in protein synthesis. Despite that, other transcripts encoding transcription factors (regulation of transcription, DNA-templated GO:0006355) were 
Table 4 Distribution in main functional categories of transcripts modulated both during the Fe-citrate and Fe-PS supply

\begin{tabular}{|c|c|c|c|c|c|c|c|}
\hline \multicolumn{2}{|l|}{ Upregulated } & \multirow[b]{2}{*}{ Counts } & \multirow[b]{2}{*}{ Fractions } & \multicolumn{2}{|c|}{ Downregulated } & \multirow[b]{2}{*}{ Counts } & \multirow[b]{2}{*}{ Fractions } \\
\hline GO Class ID & Definitions & & & GO Class ID & Definitions & & \\
\hline GO:0008150 & biological process & 21 & $25.61 \%$ & GO:0008150 & biological process & 91 & $27.74 \%$ \\
\hline GO:0009987 & cellular process & 15 & $18.29 \%$ & GO:0009987 & cellular process & 56 & $17.07 \%$ \\
\hline GO:0008152 & metabolic process & 14 & $17.07 \%$ & GO:0008152 & metabolic process & 55 & $16.77 \%$ \\
\hline GO:0009058 & biosynthetic process & 5 & $6.10 \%$ & GO:0009058 & biosynthetic process & 20 & $6.10 \%$ \\
\hline GO:0005975 & carbohydrate metabolic process & 4 & $4.88 \%$ & GO:0019538 & protein metabolic process & 14 & $4.27 \%$ \\
\hline GO:0009056 & catabolic process & 4 & $4.88 \%$ & GO:0006810 & transport & 12 & $3.66 \%$ \\
\hline GO:0019538 & protein metabolic process & 3 & $3.66 \%$ & GO:0006139 & $\begin{array}{l}\text { nucleobase, nucleoside, nucleotide and } \\
\text { nucleic acid metabolic process }\end{array}$ & 12 & $3.66 \%$ \\
\hline GO:0016043 & $\begin{array}{l}\text { cellular component organization and } \\
\text { biogenesis }\end{array}$ & 2 & $2.44 \%$ & GO:0005975 & carbohydrate metabolic process & 7 & $2.13 \%$ \\
\hline GO:0006091 & $\begin{array}{l}\text { generation of precursor metabolites and } \\
\text { energy }\end{array}$ & 2 & $2.44 \%$ & GO:0009056 & catabolic process & 7 & $2.13 \%$ \\
\hline GO:0006139 & $\begin{array}{l}\text { nucleobase, nucleoside, nucleotide and } \\
\text { nucleic acid metabolic process }\end{array}$ & 2 & $2.44 \%$ & GO:0016043 & $\begin{array}{l}\text { cellular component organization and } \\
\text { biogenesis }\end{array}$ & 6 & $1.83 \%$ \\
\hline GO:0015979 & photosynthesis & 2 & $2.44 \%$ & GO:0006950 & response to stress & 6 & $1.83 \%$ \\
\hline GO:0006950 & response to stress & 1 & $1.22 \%$ & GO:0006464 & protein modification process & 5 & $1.52 \%$ \\
\hline GO:0006810 & transport & 1 & $1.22 \%$ & GO:0006629 & lipid metabolic process & 5 & $1.52 \%$ \\
\hline GO:0007165 & signal transduction & 1 & $1.22 \%$ & GO:0006412 & translation & 4 & $1.22 \%$ \\
\hline GO:0007154 & cell communication & 1 & $1.22 \%$ & GO:0006259 & DNA metabolic process & 3 & $0.91 \%$ \\
\hline GO:0009719 & response to endogenous stimulus & 1 & $1.22 \%$ & GO:0006091 & $\begin{array}{l}\text { generation of precursor metabolites and } \\
\text { energy }\end{array}$ & 3 & $0.91 \%$ \\
\hline GO:0006412 & translation & 1 & $1.22 \%$ & GO:0016265 & death & 2 & $0.61 \%$ \\
\hline GO:0007049 & cell cycle & 1 & $1.22 \%$ & GO:0009628 & response to abiotic stimulus & 2 & $0.61 \%$ \\
\hline GO:0006629 & lipid metabolic process & 1 & $1.22 \%$ & GO:0009607 & response to biotic stimulus & 2 & $0.61 \%$ \\
\hline \multirow[t]{13}{*}{ Total } & & 82 & $100.00 \%$ & GO:0007165 & signal transduction & 2 & $0.61 \%$ \\
\hline & & & & GO:0007154 & cell communication & 2 & $0.61 \%$ \\
\hline & & & & GO:0008219 & cell death & 2 & $0.61 \%$ \\
\hline & & & & GO:0040007 & growth & 2 & $0.61 \%$ \\
\hline & & & & GO:0000003 & reproduction & 1 & $0.30 \%$ \\
\hline & & & & GO:0016049 & cell growth & 1 & $0.30 \%$ \\
\hline & & & & GO:0019725 & cell homeostasis & 1 & $0.30 \%$ \\
\hline & & & & GO:0009791 & post-embryonic development & 1 & $0.30 \%$ \\
\hline & & & & GO:0009605 & response to external stimulus & 1 & $0.30 \%$ \\
\hline & & & & GO:0009908 & flower development & 1 & $0.30 \%$ \\
\hline & & & & GO:0007275 & multicellular organismal development & 1 & $0.30 \%$ \\
\hline & & & & GO:0015979 & photosynthesis & 1 & $0.30 \%$ \\
\hline & & & & Total & & 328 & $100.00 \%$ \\
\hline
\end{tabular}

The distribution in main functional categories on the basis of "biological process" terms was performed using CateGOrizer [79] setting Plant GO slim method and consolidated single occurrences. The analysis was performed using the GO terms of the 41 and 215 transcripts positively and negatively affected respectively in response to both Fe-citrate and Fe-PS and showing homology to "known protein"

upregulated by the treatment with Fe-citrate and FePS (Table 4). Among these transcripts, one encodes for a bHLH (\#28) and the other one for a R2R3-MYB transcript (\#1). Interestingly this latter transcript is induced by all three Fe-sources (Table 2).

\section{Transcript specifically affected by Fe-citrate supply}

Among the 439 transcripts modulated exclusively by the Fe-citrate treatment, 233 were downregulated and 206 upregulated. Twenty-four downregulated and 26 upregulated transcripts did not show any sequence homology 
with known proteins ("no hits found"). The distribution analysis of the main functional categories of transcripts with homology to known proteins showed that the more abundant "biological process", "cellular process" and "metabolic process" were similarly represented both for downregulated and upregulated set of transcripts (Table 5). "Cellular component organization biogenesis", "biosynthetic process" and "nucleobase, nucleoside, nucleotide and nucleic acid metabolic process" functional categories were more represented in the downregulated transcript dataset while "signal transduction" in the upregulated transcript dataset (Table 5).

The analysis of downregulated transcripts showed that in addition to those involved in carbohydrate metabolism and TCA cycle above discussed, other genes related to glycolysis (i.e. triose-phosphate isomerase, TIM, \#29) and

Table 5 Distribution in main functional categories of transcripts specifically affected by Fe-citrate supply

\begin{tabular}{|c|c|c|c|c|c|c|c|}
\hline \multicolumn{4}{|l|}{ Upregulated } & \multicolumn{4}{|c|}{ Downregulated } \\
\hline GO Class ID & Definitions & Counts & Fractions & GO Class ID & Definitions & Counts & Fractions \\
\hline GO:0008150 & biological_process & 59 & $29.35 \%$ & GO:0008150 & biological_process & 93 & $28.53 \%$ \\
\hline GO:0009987 & cellular process & 38 & $18.91 \%$ & GO:0009987 & cellular process & 59 & $18.10 \%$ \\
\hline GO:0008152 & metabolic process & 31 & $15.42 \%$ & GO:0008152 & metabolic process & 48 & $14.72 \%$ \\
\hline GO:0019538 & protein metabolic process & 9 & $4.48 \%$ & GO:0016043 & $\begin{array}{l}\text { cellular component organization } \\
\text { and biogenesis }\end{array}$ & 17 & $5.21 \%$ \\
\hline GO:0006950 & response to stress & 7 & $3.48 \%$ & GO:0009058 & biosynthetic process & 17 & $5.21 \%$ \\
\hline GO:0006810 & transport & 7 & $3.48 \%$ & GO:0019538 & protein metabolic process & 15 & $4.60 \%$ \\
\hline GO:0009058 & biosynthetic process & 6 & $2.99 \%$ & GO:0006810 & transport & 12 & $3.68 \%$ \\
\hline GO:0006139 & $\begin{array}{l}\text { nucleobase, nucleoside, nucleotide and } \\
\text { nucleic acid metabolic process }\end{array}$ & 6 & $2.99 \%$ & GO:0006139 & $\begin{array}{l}\text { nucleobase, nucleoside, nucleotide } \\
\text { and nucleic acid metabolic process }\end{array}$ & 12 & $3.68 \%$ \\
\hline GO:0016043 & $\begin{array}{l}\text { cellular component organization and } \\
\text { biogenesis }\end{array}$ & 5 & $2.49 \%$ & GO:0009056 & catabolic process & 9 & $2.76 \%$ \\
\hline GO:0007165 & signal transduction & 4 & $1.99 \%$ & GO:0006950 & response to stress & 5 & $1.53 \%$ \\
\hline GO:0007154 & cell communication & 4 & $1.99 \%$ & GO:0005975 & carbohydrate metabolic process & 4 & $1.23 \%$ \\
\hline GO:0009056 & catabolic process & 4 & $1.99 \%$ & GO:0007154 & cell communication & 4 & $1.23 \%$ \\
\hline GO:0009719 & response to endogenous stimulus & 3 & $1.49 \%$ & GO:0006464 & protein modification process & 4 & $1.23 \%$ \\
\hline GO:0006464 & protein modification process & 3 & $1.49 \%$ & GO:0006412 & translation & 4 & $1.23 \%$ \\
\hline GO:0009628 & response to abiotic stimulus & 2 & $1.00 \%$ & GO:0007165 & signal transduction & 3 & $0.92 \%$ \\
\hline GO:0005975 & carbohydrate metabolic process & 2 & $1.00 \%$ & GO:0006091 & $\begin{array}{l}\text { generation of precursor } \\
\text { metabolites and energy }\end{array}$ & 3 & $0.92 \%$ \\
\hline GO:0015979 & photosynthesis & 2 & $1.00 \%$ & GO:0015979 & photosynthesis & 3 & $0.92 \%$ \\
\hline GO:0006629 & lipid metabolic process & 2 & $1.00 \%$ & GO:0006259 & DNA metabolic process & 2 & $0.61 \%$ \\
\hline GO:0016265 & death & 1 & $0.50 \%$ & GO:0009719 & response to endogenous stimulus & 2 & $0.61 \%$ \\
\hline GO:0006259 & DNA metabolic process & 1 & $0.50 \%$ & GO:0006629 & lipid metabolic process & 2 & $0.61 \%$ \\
\hline GO:0019725 & cell homeostasis & 1 & $0.50 \%$ & GO:0000003 & reproduction & 1 & $0.31 \%$ \\
\hline GO:0006091 & $\begin{array}{l}\text { generation of precursor metabolites } \\
\text { and energy }\end{array}$ & 1 & $0.50 \%$ & GO:0009628 & response to abiotic stimulus & 1 & $0.31 \%$ \\
\hline GO:0008219 & cell death & 1 & $0.50 \%$ & GO:0009875 & pollen-pistil interaction & 1 & $0.31 \%$ \\
\hline GO:0006412 & translation & 1 & $0.50 \%$ & GO:0019725 & cell homeostasis & 1 & $0.31 \%$ \\
\hline GO:0007049 & cell cycle & 1 & $0.50 \%$ & GO:0009856 & pollination & 1 & $0.31 \%$ \\
\hline \multirow[t]{4}{*}{ Total } & & 201 & $100.00 \%$ & GO:0009653 & $\begin{array}{l}\text { anatomical structure } \\
\text { morphogenesis }\end{array}$ & 1 & $0.31 \%$ \\
\hline & & & & GO:0007275 & $\begin{array}{l}\text { multicellular organismal } \\
\text { development }\end{array}$ & 1 & $0.31 \%$ \\
\hline & & & & GO:0019748 & secondary metabolic process & 1 & $0.31 \%$ \\
\hline & & & & Total & & 326 & $100.00 \%$ \\
\hline
\end{tabular}

The distribution in main functional categories on the basis of "biological process" terms was performed using CateGOrizer [79] setting Plant GO slim method and consolidated single occurrences. The analysis was performed using the GO terms of the 180 and 209 transcripts positively and negatively affected respectively in response to Fe citrate and showing homology to "known protein" 
pentose phosphate pathway (i.e. 6-phosphogluconate dehydrogenase, PGD, \#30) were negatively affected (Table 2). A similar behaviour was observed for transcripts of the TCA cycles (pyruvate dehydrogenase E1 beta subunit transcript, PDC, \#31; citrate synthase, CS, \#32) and of the alternative pathway via PEPC (i.e. a transcript encoding PEPC, \#33) (Table 2). Two NADH dehydrogenase (NDH) transcripts (\#34 and \#35) and another one showing homology to the tobacco prohibitin 2 (NbPHB2, \#36), which is involved in stress tolerance stabilizing the mitochondrial function [53], were found to be repressed by Fe-citrate treatment. This might be explained as a specific regulation of TCA cycle and mitochondrial activity when Fe is supplied as Fe-citrate, bearing in mind that this organic acid might be absorbed by roots [54].

Other processes related to protein synthesis ("translation", "translational initiation" and "protein folding"; Table 5) and protein catabolism were mainly repressed (downregulated) in response to Fe-citrate treatment. On the other hand, in the same treatment the functional categories of protein modification processes (e.g. phosphorylation and proteolysis) were similarly represented both for downregulated and upregulated sets of transcripts (Table 5).

The supply with Fe-citrate caused the upregulation of a transcript encoding the Fe-containing enzyme nitrite reductase (NiR, \#37, Table 2). This evidence might indicate the restoration of nitrate assimilation, which is known to be altered in Fe-deficient conditions [55]. Besides those involved in protein turnover (see above), other genes putatively related to $\mathrm{N}$ recycling were found to be downregulated, such as plastid GS (\#38) and ferredoxin-dependent glutamate synthase 1 (GLU, \#39).

In addition, $\mathrm{Fe}$-citrate caused the modulation in either directions of transcripts involved in the cell wall metabolism (i.e. extensin, EXT, \#40, \#41, \#42 and \#43; pectinesterase, PE, \#44 and \#45), in oxidative stress (\#46, \#47, $\# 48, \# 49, \# 50$ and $\# 51$ ) and encoding heat-shock proteins (\#52, \#53, \#54, \#55, \#56 and \#57) (Table 2). These results suggest that the modulation of these processes might be related on one side to the changing of Fe nutritional status, and on the other side to the presence of citrate.

Interestingly, many transcripts involved in the regulation of plant defence response such as Avr/Cf-9 rapidly elicited (ACRE) genes (\#58, \#59, \#60, \#61, \#62, \#63, \#64 and \#65) and those encoding WRKYs (\#66, \#67, \#68, \#69 and \#70) were induced by the Fe-citrate supply (Table 2). The activity of these transcripts could be related to the avoidance of $\mathrm{Fe}$ toxicity. The involvement of ACRE genes in the response to Al-toxicity in rice roots [56] and the role of a WRKY rice protein in response to excess of Fe [57] has been reported. A similar role in response to Fe toxicity could be ascribed to the upregulation of transcripts belonging to GAI, RGA, RCS (GRAS) gene family (\#71, \#72, \#73, \#74, \#75, \#76 and \#77, Table 2). GRAS proteins play a role in the regulation of root growth, nodulation signalling and response to environmental stresses [58]; furthermore, members of this gene family are involved in disease resistance and mechanical stress response in tomato [59].

\section{Transcript specifically affected by Fe-PS supply}

One hundred and nineteen transcripts were specifically modulated in tomato roots by Fe-PS treatment (Fig. 3; Additional file 3: Table S4), 82 and 37 in a negative and in a positive way, respectively. Twenty-one downregulated and ten upregulated transcripts did not show any homology to known proteins ("no hit found", Additional file 3: Table S4). The distribution in main functional categories highlighted that for the Fe-PS specific transcripts the most abundant categories are "biological process", "cellular process", "metabolic process", "protein metabolic process" and "nucleobase, nucleoside, nucleotide and nucleic acid metabolic process" (Table 6). Transcripts related to "lipid metabolic process" are mainly negatively affected (Table 2) such as those encoding a 3-hydroxyacyl-CoA dehydrogenase (HADH, \#78), a fatty acid desaturase (FADS, \#79), an acyl-CoA synthetase (ACS, \#80) and a phospholipase C (PLC, \#81) while only a lipid metabolism-related transcripts, encoding a delta(14)sterol reductase (Delta-14-SR, \#82) was upregulated. In addition to the phospholipase C (PLC) transcript, the treatment with Fe-PS repressed the expression of another transcript encoding a phosphatidic-acid phosphatase (\#83, Table 2) suggesting that this Fe source can specifically affect the phospholipid-based signal, which is involved in plant environmental responses $[60,61]$. It has been shown that the repression of plant PLCs is related to the response to toxic metals, such as $\mathrm{Al}^{3+}$ and $\mathrm{Cd}^{2+}$, that implies limiting ROS generation and lipid peroxidation [61,62]. Iron-PS might negatively affect the phospholipid-based signal that controls responses to $\mathrm{Fe}$, possibly through the reduction of ROS as suggested by the downregulation of an ascorbate oxidase (AO) transcript (\#84, Table 2). This AO gene is involved in ascorbic acid biosynthesis in tomato [63] playing an important role as an antioxidant and protecting plant cells during oxidative damage by scavenging free radicals and ROS. On the basis of these results, it might be speculated that $\mathrm{Fe}$ is present within the root cells as Fe-PS complex and that this Fe-form could limit Fe-induced ROS production. Indeed there is some evidence that Strategy I plants can directly take up Fe-PS complexes [35]. The idea that tomato roots could at least in part adsorb the Fe-PS complexes is supported by the observation that a transcript encoding an oligopeptide transporter "Yellow stripe-like protein" (\#85, Solyc03g031920.2.1) 
Table 6 Distribution in main functional categories of transcripts specifically affected by Fe-PS supply

\begin{tabular}{|c|c|c|c|c|c|c|c|}
\hline \multicolumn{4}{|l|}{ Upregultated } & \multicolumn{4}{|c|}{ Downregulated } \\
\hline GO Class ID & Definitions & Counts & Fractions & GO Class ID & Definitions & Counts & Fractions \\
\hline GO:0008150 & biological_process & 19 & $27.94 \%$ & GO:0008150 & biological_process & 32 & $29.36 \%$ \\
\hline GO:0008152 & metabolic process & 14 & $20.59 \%$ & GO:0008152 & metabolic process & 20 & $18.35 \%$ \\
\hline GO:0009987 & cellular process & 11 & $16.18 \%$ & GO:0009987 & cellular process & 19 & $17.43 \%$ \\
\hline GO:0009058 & biosynthetic process & 5 & $7.35 \%$ & GO:0019538 & protein metabolic process & 6 & $5.50 \%$ \\
\hline GO:0019538 & protein metabolic process & 5 & $7.35 \%$ & GO:0006139 & $\begin{array}{l}\text { nucleobase, nucleoside, nucleotide } \\
\text { and nucleic acid metabolic process }\end{array}$ & 5 & $4.59 \%$ \\
\hline GO:0006139 & $\begin{array}{l}\text { nucleobase, nucleoside, nucleotide } \\
\text { and nucleic acid metabolic process }\end{array}$ & 2 & $2.94 \%$ & GO:0006629 & lipid metabolic process & 4 & $3.67 \%$ \\
\hline GO:0006464 & protein modification process & 2 & $2.94 \%$ & GO:0006810 & transport & 3 & $2.75 \%$ \\
\hline GO:0005975 & carbohydrate metabolic process & 2 & $2.94 \%$ & GO:0006464 & protein modification process & 3 & $2.75 \%$ \\
\hline GO:0009056 & catabolic process & 2 & $2.94 \%$ & GO:0005975 & carbohydrate metabolic process & 3 & $2.75 \%$ \\
\hline GO:0006810 & transport & 1 & $1.47 \%$ & GO:0016043 & $\begin{array}{l}\text { cellular component organization } \\
\text { and biogenesis }\end{array}$ & 2 & $1.83 \%$ \\
\hline GO:0007165 & signal transduction & 1 & $1.47 \%$ & GO:0007165 & signal transduction & 2 & $1.83 \%$ \\
\hline GO:0007154 & cell communication & 1 & $1.47 \%$ & GO:0007154 & cell communication & 2 & $1.83 \%$ \\
\hline GO:0006091 & $\begin{array}{l}\text { generation of precursor metabolites and } \\
\text { energy }\end{array}$ & 1 & $1.47 \%$ & GO:0006950 & response to stress & 2 & $1.83 \%$ \\
\hline GO:0006412 & translation & 1 & $1.47 \%$ & GO:0009058 & biosynthetic process & 2 & $1.83 \%$ \\
\hline GO:0006629 & lipid metabolic process & 1 & $1.47 \%$ & GO:0009056 & catabolic process & 2 & $1.83 \%$ \\
\hline \multirow[t]{3}{*}{ Total } & & 68 & $100.00 \%$ & GO:0006259 & DNA metabolic process & 1 & $0.92 \%$ \\
\hline & & & & GO:0009719 & response to endogenous stimulus & 1 & $0.92 \%$ \\
\hline & & & & Total & & 109 & $100.00 \%$ \\
\hline
\end{tabular}

The distribution in main functional categories on the basis of "biological process" terms was performed using CateGOrizer [79] setting Plant GO slim method and consolidated single occurrences. The analysis was performed using the GO terms of the 27 and 61 transcripts positively and negatively affected respectively in response to Fe-PS and showing homology to "known protein"

was repressed after $1 \mathrm{~h}$ of Fe-PS treatment. The rapid back-regulation of this putative Fe-PS transporter would indicate a secondary role in Fe nutrition of tomato plants, while possibly having a role in preventing oxidative damages in the early stages of Fe supply.

A gene encoding the gibberellin 20 oxidase (GA20OX, \#86, Table 2), previously hypothesized acting in tomato root morphological changes in response to Fe deficiency [5], was one of those specifically downregulated by $\mathrm{Fe}$ PS supply.

Furthermore, the Fe-PS treatment specifically modulated transcripts encoding transcription factors in a negative (i.e. TGA10, \#87; GRAS, \#88; bHLH JAF13, \#89) and in a positive way (Myb-like protein, \#90; Homeobox-leucine zipper protein, \#91) (Table 2). GRAS transcripts were positively modulated in response to Fe-citrate treatment while, in the case of Fe-PS, one GRAS transcript was downregulated. Our results suggest that some transcription factors could play a role in the response to Fe supply common to different Fe sources, such as the R2R3 MYB transcription factor (\#1; Solyc06g005310.2.1, Table 2), while others could be specific for the control of genes and pathways selectively modulated in response to each Fe-source.

\section{Conclusions}

Our results suggest that the root transcriptional response to Fe supply depends on the nature of the ligand (WEHS, citrate and PS). The supply with Fe-WEHS, which has been demonstrated to be able to enhance Fe acquisition responses in Strategy I plants [23, 36], did not cause relevant changes in the root transcriptome with respect to the Fe-deficient plants, indicating that roots did not sense the restored cellular Fe accumulation. This result could explain the higher Fe concentration observed after 4 and $24 \mathrm{~h}$ in tomato plant tissues supplied with Fe-WEHS as compared to the other Fe-sources. This behaviour is confirmed by a faster and more efficient Fe allocation in the leaf tissue [37]. As a result, Fe-WEHS supply would favour a better distribution of Fe within the plant.

The transcriptional behaviour of tomato roots with the other two natural Fe-sources, Fe-citrate and Fe-PS, underlined that the supply responses are fast and based on a back regulation of molecular mechanisms modulated 
under Fe deficiency. We also observed some responses specific for each of the two natural Fe sources suggesting a transcriptional response in roots to the molecule used to chelate the micronutrient. Considering transcripts specifically regulated by Fe-citrate, we could hypothesize that citrate is also absorbed by roots causing a further negative regulation of the TCA cycle and influencing mainly cell wall metabolism and the response regulation to stress. Iron-PS specific responses seem to be mainly based on a negative regulation of lipid metabolism and phospholipidbased signal that control ROS responses in the presence of heavy metals.

\section{Methods}

Water extractable humic substances (WEHS) were isolated as reported by Pinton et al. [64] and FeWEHS complexes were prepared as described by Cesco et al. [31] by mixing $5 \mu \mathrm{g}$ organic carbon (Corg) of WEHS fraction for each $\mu \mathrm{mol}$ of $\mathrm{FeCl}_{3}$. A thorough chemical characterization of the fractions is described elsewhere [23].

Phytosiderophores (PS) were collected in the root exudate of Fe-deficient barley plants as described by Tomasi et al. [22]. Iron-PS and Fe-citrate were prepared accordingly to von Wirén et al. [65] by mixing an aliquot of Fe-free-PS or citrate (10\% excess of the chelating agent) with $\mathrm{FeCl}_{3}$. For radiochemical experiments, ${ }^{59} \mathrm{FeCl}_{3}$ was utilized at the specific labeling activity of $144 \mathrm{kBq} \mu \mathrm{mol}^{-1} \mathrm{Fe}$ (Perkin Elmer, Monza, Italy).

\section{Plant material and growth conditions}

Tomato seedling (Solanum lycopersicum L., cv. 'Marmande superprecoce,' DOTTO Spa, Italy) were first germinated for 6 days on filter paper moistened with $1 \mathrm{mM}$ $\mathrm{CaSO}_{4}$ and consequently grown for other 14 days in a continuously aerated nutrient solution ( $\mathrm{pH}$ adjusted at 6.0 with $1 \mathrm{M} \mathrm{KOH}$ ) as reported by Tomasi at al. [22] with $5 \mu \mathrm{M} \mathrm{Fe}$ (Fe-EDTA); thereafter, most of the plants were transferred for a further week to a Fe-free nutrient solution (Fe-deficient) and some tomato plants were transferred for a week to a nutrient solution containing $100 \mu \mathrm{M}$ Fe-EDTA (Fe-sufficient plants) as control for the $\mathrm{Fe}(\mathrm{III})$-chelate reductase activity. Nutrient solutions were renewed every 3 days. The controlled climatic conditions were the following: day/night photoperiod, $16 / 8 \mathrm{~h}$; light intensity, $220 \mu \mathrm{E} \mathrm{m}^{-2} \mathrm{~s}^{-1}$; temperature (day/ night) $25 / 20{ }^{\circ} \mathrm{C}$; RH 70 to $80 \%$.

At the end of the growing period (27 days), Fedeficient tomato plants clearly showed visible symptoms of Fe deficiency: yellowing of the fully expanded apical leaves, proliferation of lateral roots and root hairs and increase in the diameter of the sub-apical root zone. Twenty-four hours before harvesting, all nutrient solutions were renewed and the $\mathrm{pH}$ was adjusted to 7.5 with
$10 \mathrm{mM}$ 4-(2-hydroxyethyl)-1 piperazineethanesulfonic acid (HEPES)-KOH. The $\mathrm{pH}$ of the growing medium was adjusted to this value to mimic as close as possible the conditions that are occurring in Fe-deficientinducing soil conditions where plant availability of $\mathrm{Fe}$ is reduced. Four hours after the beginning of the light phase, natural Fe-sources (Fe-citrate, $\mathrm{Fe}$-PS or FeWEHS) were added to the nutrient solution of $\mathrm{Fe}$ deficient tomato plants to obtain a final concentrations of $1 \mu \mathrm{M}$ Fe. The same experimental setup was used for radiochemical analyses with ${ }^{59} \mathrm{Fe}$-citrate, ${ }^{59} \mathrm{Fe}-\mathrm{PS}$ or ${ }^{59} \mathrm{Fe}$-WEHS treatments. The treatment with the three Fe sources lasted up to $24 \mathrm{~h}$; during this period, plant samples were harvested and used for the analyses described below.

For transcriptional analyses, after $1 \mathrm{~h}(5 \mathrm{~h}$ from the beginning of light phase), tomato plants were harvested and collected roots were immediately frozen in liquid nitrogen and stored until further processing at $-80{ }^{\circ} \mathrm{C}$. The collection was repeated in three independent cultivations and the roots from six plants were pooled for each treatment. As control, Fe-deficient tomato plants were utilized (without any addition of external Fe sources) prepared in the same experiments and used for the analyses previously presented in Zamboni et al. [5].

\section{${ }^{59} \mathrm{Fe}$ uptake from natural Fe sources and ferric-chelate reduction capability by roots of intact plants}

After 1,4 or $24 \mathrm{~h}$ of treatment with ${ }^{59} \mathrm{Fe}$ complexes, plants were transferred to a freshly prepared ${ }^{59} \mathrm{Fe}$-free nutrient solution for $10 \mathrm{~min}$ in order to remove the excess of ${ }^{59} \mathrm{Fe}$ at the root surface, and then harvested dividing roots and leaves [66]. Root apoplastic ${ }^{59} \mathrm{Fe}$ pools were removed using $1.2 \mathrm{~g} \mathrm{~L}^{-1}$ sodium dithionite and

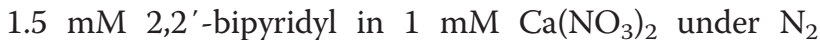
bubbling as described by Bienfait et al. [67]; the treatment was repeated three times.

Root and leaf tissues were oven-dried at $80{ }^{\circ} \mathrm{C}$, weighed, ashed at $550{ }^{\circ} \mathrm{C}$ and suspended in $1 \%(\mathrm{w} / \mathrm{v})$ $\mathrm{HCl}$ for ${ }^{59} \mathrm{Fe}$ determination by liquid scintillation counting. The ${ }^{59} \mathrm{Fe}$ uptake, measured as $\mu \mathrm{g}{ }^{59} \mathrm{Fe}$, is referred to the whole plant (root + leaves) and is presented per $\mathrm{g}$ root dry weight .

To determine the root capacity to reduce the Fe(III)chelates, roots of a single intact (Fe-sufficient or Fedeficient with or without $1 \mathrm{~h}$ supply) tomato plants were incubated in the dark at $25{ }^{\circ} \mathrm{C}$ for $60 \mathrm{~min}$ in $50 \mathrm{~mL}$ of an aerated solution containing $\mathrm{CaSO}_{4} 0.5 \mathrm{mM}$, bathophenanthroline disulfonate sodium salt (BPDS) $0.5 \mathrm{mM}$, 2-( $N$-morpholino)ethanesulfonic acid (MES)-KOH 10 $\mathrm{mM}$ (pH 5.5). Thereafter, the absorbance of the solutions was measured at $535 \mathrm{~nm}$ at intervals of $15 \mathrm{~min}$ and the concentration of $\mathrm{Fe}(\mathrm{III})$ reduced calculated by the 
concentration of the $\mathrm{Fe}(\mathrm{II})-\mathrm{BPDS}_{3}$ complex formed, using an extinction coefficient of $22.1 \mathrm{mM}^{-1} \mathrm{~cm}^{-1}$.

\section{RNA extraction and microarray analyses}

Transcriptional analysis was carried out using a Combimatrix chip [68], produced by the Functional Genomics Lab., University of Verona [69]. The chip (TomatoArray2.0) carries 25,789 nonredundant probes (23,282 unique probes and 2507 probes with more than one target) randomly distributed in triplicate across the array, each comprising a 35-40-mer oligonucleotide designed using the program oligoarray 2.1 [70]. The source of sequence information included tentative consensus sequences (TCs) derived from the DFCI Tomato Gene Index [71] Release 12.0 and expressed sequence tags. Eight bacterial oligonucleotide sequences provided by CombiMatrix, 8 probes designed on 8 Ambion spikes and 40 probes based on Bacillus anthracis, Haemophilus ducreyi and Alteromonas phage sequences were used as negative controls. Complete description of the chip is available at the Gene Expression Omnibus [72] under the series entry (GPL13934).

Total RNA was isolated using the SpectrumTM Plant Total RNA kit (Sigma-Aldrich) and quantified by spectrophotometry using NanoDrop ${ }^{\mathrm{Tw}} 1000$ (Thermo Scientific). RNA quality was evaluated using Agilent 2100 Bioanalyzer (Agilent). Total RNA $(1 \mu \mathrm{g})$ was amplified and labelled using the RNA ampULSe kit (Kreatech). After checking the quantity and quality of antisense (aRNA) by spectrophotometry using NanoDrop ${ }^{\mathrm{Tx}} 1000$ (Thermo Scientific) and the quality subsequent labelling, $4 \mu \mathrm{g}$ of labelled aRNA was hybridized to the array according to the manufacturer's recommendations [68]. Pre-hybridization, hybridization, washing and imaging were performed according to the manufacturer's protocols. The array was scanned with an Axon GenePix ${ }^{\circ}$ 4400A scanner (MDS Analytical Technologies).

Analysis of raw data was performed using the open source software of the Bioconductor project [73, 74] with the statistical $R$ programming language $[75,76]$. Background adjustment, summarization and quantile normalization were performed using limma package. Probes expressed in all three biological replicates were considered otherwise probes were removed. Differentially expressed probes were identified by linear models analysis [39] using limma package and applying Bayesian correction, adjusted $p$-value of 0.05 and a FC $\geq 2$. All microarray expression data are available at the Gene Expression Omnibus [72] under the series entry (GSE69419). The data obtained by Fe-deficient and Fe-sufficient plants used in the experiments presented in Zamboni et al. [5] were used as control and submitted with the GEO code: GSE31112. Differentially expressed transcripts between Fe-deficient plants supply for $1 \mathrm{~h}$ with the three natural $\mathrm{Fe}$ sources and Fe-deficient plants were grouped in main functional categories according to the "biological" terms of the Gene Ontology [30] assigned to each tomato TC or EST (Release 12.0) on the basis of the results of BlastP analysis [77] against the UniProt database [42] (Additional file 3: Table S4). Genes without significant BlastP results were classified as "no hits found" (Evalue $<1 \mathrm{e}-8$; identity $>40 \%$ ).

\section{Real-time RT-PCR experiments}

Five hundreds nanograms of total RNA (isolated as previously described) of each sample was retrotranscribed using 1 pmol of Oligo d(T)23VN (New England Biolabs, Beverly, USA) and $10 \mathrm{U}$ M-MulV RNase $\mathrm{H}^{-}$for $1 \mathrm{~h}$ at $42^{\circ}$ $\mathrm{C}$ (Finnzymes, Helsinki, Finland) following the application protocol of the manufacturers. After RNA digestion with $1 \mathrm{U}$ RNase A (USB, Cleveland, USA) for $1 \mathrm{~h}$ at $37^{\circ} \mathrm{C}$, gene expression analyses were performed by adding $0.16 \mu \mathrm{L}$ of the cDNA to the realtime PCR complete mix, FluoCycle $^{\mathrm{TM}}$ sybr green $(20 \mu \mathrm{L}$ final volume; Euroclone, Pero, Italy), in a DNA Engine Opticon Real-Time PCR Detection (Biorad, Hercules, USA). Specific primers $\left(\mathrm{Tm}=58^{\circ}\right.$ C) were designed to generate $80-150$ bp PCR products. Three genes were used as housekeeping to normalize the data: LeEF1a, coding for 1-alpha elongation factor (X14449), LeH1, coding for histone protein (AJ224933) and LeUbi3, coding for an ubiquitin protein (X58253). Each Real-Time RT-PCR was performed 4 times on 3 independent experiments; analyses of real-time result were performed using Opticon Monitor 2 software (Biorad, Hercules, USA) and R [74-76], with the qpcR package [78]. Efficiencies of amplification were calculated following the authors' indications. Sequences of forward and reverse primers and efficiencies were reported in Additional file 1: Table S5 gene.

\section{Additional files}

\begin{abstract}
Additional file 1: Figure S1. Cluster heat map of gene expression data. Table S1. Results of Real-time RT-PCR experiments performed for a set of transcripts resulted differentially expressed in the different comparison of microarray analysis. Table S2. Number of differentially expressed transcripts resulted by root transcriptional profile comparisons of Fe-deficient plants supplied for $1 \mathrm{~h}$ with the three natural sources of Fe and Fe-sufficient plants. Figure S2. Shared transcripts modulated in Fe-deficient plants after $1 \mathrm{~h}$ in response to supply with the three natural Fe sources relative to Fe-sufficient plants. Table S5. Sequence of forward and reverse primers used in Realtime RT-PCR experiments. (PDF $2631 \mathrm{~kb}$ )
\end{abstract}

Additional file 2: Table S3. Differentially expressed transcripts resulted by the comparison of root transcriptional profiles of Fe-deficient plants supplied for $1 \mathrm{~h}$ with Fe-WEHS, Fe-citrate and Fe-PS with root transcriptional profile of Fe-sufficient plants. Probe ID, adjusted $p$-value and $\log _{2}(R)$ were reported for each transcript. (XLS $174 \mathrm{~kb}$ )

Additional file 3: Table S4. Functional annotation of differentially expressed transcripts resulted by the comparison of root transcriptional profiles of Fe-deficient plants supplied for $1 \mathrm{~h}$ with Fe-citrate, Fe-PS and Fe-WEHS with root transcriptional profile of Fe-deficient plants. Probe ID, description, species, identity, score, e-value, Uniprot entry and biological 
$\mathrm{GO}$ term were reported. The adjusted $p$-value and $\mathrm{Log}_{2}(\mathrm{R})$ were also reported for each transcript. (XLSX $130 \mathrm{~kb}$ )

\section{Competing interests}

The authors declare that they have no competing interests.

\section{Authors' contributions}

AZ and LZ made a substantial contribution to data collection and interpretation and manuscript drafting. NT participated in the project's design, data analysis and manuscript revision. LA critically revised the manuscript. RP contributed to data interpretation and critically revised the manuscript. ZV contributed to data interpretation and manuscript writing. SC participated in the project's design and coordination and critically revised the manuscript. All authors read and approved the final manuscript.

\section{Acknowledgements}

We thank the Functional Genomics Lab of University of Verona for production of Combimatrix chip and assistance in microarray experiments. This work was support by grants: MIUR (FIRB-Futuro in Ricerca) and JP Univr (FEDEFRO). We thank Dr Tanja Mimmo for a final improvement of the English.

\section{Author details}

1 Department of Biotechnology, University of Verona, via delle Grazie 15, 37134 Verona, Italy. ${ }^{2}$ Department of Agriculture and Environmental Sciences, University of Udine, via delle Scienze 208, 33100 Udine, Italy. ${ }^{3}$ Faculty of Science and Technology, Free University of Bolzano, piazza Università 5, 39100 Bolzano, Italy.

\section{Received: 6 June 2015 Accepted: 17 December 2015}

\section{Published online: 07 January 2016}

\section{References}

1. Kobayashi T, Nishizawa. Iron uptake, translocation, and regulation in higher plants. Annu Rev Plant Biol. 2012;63:131-52.

2. Mimmo T, Del Buono D, Terzano R, Tomasi N, Vigani G, Crecchio C, et al. Rhizospheric organic compounds in the soil-microorganism-plant system: their role in iron availability. Europ J Soil Sci. 2014. doi:10.1111/ejss.12158.

3. Brumbarova T, Bauer P, Ivanov R. Molecular mechanisms governing Arabidopsis iron uptake. Trends Plant Sci. 2015;20(2):124-33.

4. Schmidt W, Buckhout TJ. A hitchhiker's guide to the Arabidopsis ferrome. Plant Physiol Biochem. 2011;49(5):462-70.

5. Zamboni A, Zanin L, Tomasi N, Pezzotti M, Pinton R, Varanini Z, et al. Genome-wide microarray analysis of tomato roots showed defined responses to iron deficiency. BMC Genomics. 2012;13:101.

6. Li H, Wang L, Yang ZM. Co-expression analysis reveals a group of genes potentially involved in regulation of plant response to iron-deficiency. Gene. 2015;554(1):16-24.

7. Thimm O, Essigmann B, Kloska S, Altmann T, Buckhout TJ. Response of Arabidopsis to iron deficiency stress as revealed by microarray analysis. Plant Physiol. 2001;127(3):1030-43.

8. Colangelo EP, Guerinot ML. The essential bHLH protein FIT1 is required for the iron deficiency response. Plant Cell. 2004;16(12):3400-12.

9. O'Rourke JA, Graham MA, Vodkin L, Gonzalez DO, Cianzio SR, Shoemake RC. Recovering from iron deficiency chlorosis in near-isogenic soybeans: a microarray study. Plant Physiol Biochem. 2007:45(5):287-92.

10. O'Rourke JA, Charlson DV, Gonzalez DO, Vodkin LO, Graham MA, Cianzio SR, et al. Microarray analysis of iron deficiency chlorosis in near-isogenic soybean lines. BMC Genomics. 2007:8:476.

11. Dinneny JR, Long TA, Wang JY, Jung JW, Mace D, Pointer S, et al. Cell identity mediates the response of Arabidopsis roots to abiotic stress. Science. 2008;320(5878):942-5.

12. Buckhout TJ, Yang TJ, Schmidt W. Early iron-deficiency-induced transcriptional changes in Arabidopsis roots as revealed by microarray analyses. BMC Genomics. 2009;10:147.

13. O'Rourke JA, Nelson RT, Grant D, Schmutz J, Grimwood J, Cannon S, et al. Integrating microarray analysis and the soybean genome to understand the soybeans iron deficiency response. BMC Genomics. 2009;10:376.

14. Forner-Giner MA, Llosá MJ, Carrasco JL, Pérez-Amador MA, Navarro L, Ancillo G. Differential gene expression analysis provides new insights into the molecular basis of iron deficiency stress response in the citrus rootstock Poncirus trifoliata (L.) Raf. J Exp Bot. 2010;61(2):483-90.

15. Yang TJ, Lin WD, Schmidt W. Transcriptional profiling of the Arabidopsis iron deficiency response reveals conserved transition metal homeostasis networks. Plant Physiol. 2010;152(4):2130-41.

16. Rodríguez-Celma J, Pan IC, Li W, Lan P, Buckhout TJ, Schmidt W. The transcriptional response of Arabidopsis leaves to Fe deficiency. Front Plant Sci. 2013;4:276.

17. Li Y, Wang N, Zhao F, Song X, Yin Z, Huang R, et al. Changes in the transcriptomic profiles of maize roots in response to iron-deficiency stress. Plant Mol Biol. 2014;85(4-5):349-63.

18. Rellán-Alvarez R, Andaluz S, Rodríguez-Celma J, Wohlgemuth G, Zocchi G, Alvarez-Fernández A, et al. Changes in the proteomic and metabolic profiles of Beta vulgaris root tips in response to iron deficiency and resupply. BMC Plant Biol. 2010;10:120.

19. Rodríguez-Celma J, Lattanzio G, Jiménez S, Briat JF, Abadía J, Abadía A, et al. Changes induced by Fe deficiency and Fe resupply in the root protein profile of a peach-almond hybrid rootstock. J Proteome Res. 2013:12(3):1162-72.

20. Rellán-Álvarez R, El-Jendoubi H, Wohlgemuth G, Abadía A, Fiehn O, Abadía J, et al. Metabolite profile changes in xylem sap and leaf extracts of strategy I plants in response to iron deficiency and resupply. Front Plant Sci. 2011;2:66.

21. Lindsay $W L$, Schwab AP. The chemistry of iron in soils and its availability to plants. J Plant Nutr. 1982;5(4-7):821-40.

22. Tomasi N, Rizzardo C, Monte R, Gottardi S, Jelali N, Terzano R, et al. Micro-analytical, physiological and molecular aspects of Fe acquisition in leaves of Fe-deficient tomato plants re-supplied with natural Fe-complexes in nutrient solution. Plant Soil. 2009;325(1-2):25-38.

23. Tomasi N, De Nobili M, Gottardi S, Zanin L, Mimmo T, Varanini Z, et al. Physiological and molecular characterization of Fe acquisition by tomato plants from natural Fe complexes. Biol Fertil Soils. 2013:49(2):187-200.

24. Römheld $V$. Existence of two different strategies for the acquisition of iron in higher plants. In: Winkelmann G, van der Helm D, Neilands JB, Weinheim DE, Chemie VCH, editors. Iron transport in animal, plants and micro- organisms. 1987. p. 353-74.

25. Jones DL, Darrah P, Kochian L. Critical evaluation of organic acid mediated iron dissolution in the rhizosphere and its potential role in root iron uptake. Plant Soil. 1996;180(1):57-66

26. Cesco S, Neumann G, Tomasi N, Pinton R, Weisskopf L. Release of plantborne flavonoids into the rhizosphere and their role in plant nutrition. Plant Soil. 2010;329(1-2):1-25

27. Cesco S, Mimmo T, Tonon G, Tomasi N, Pinton R, Terzano R, et al. Plantborne flavonoids released into the rhizosphere: impact on soil bio-activities related to plant nutrition. A review. Biol Fertil Soils. 2012:48:123-49.

28. Ma JF, Nomoto K. Effective regulation of iron acquisition in graminaceous plants. The role of mugineic acids as phytosiderophores. Physiol Plant. 1996; 97(3):609-17.

29. Shenker M, Oliver I, Helmann M, Hadar Y, Chen Y. Utilization by tomatoes of iron mediated by a siderophore produced by Rhizopus arrhizus. J Plant Nutr. 1992:15(10):2173-82.

30. Stevenson FJ. Organic matter-micronutrient reactions in soil. In: Mortvedt JJ, Cox FR, Schuman LM, Welch RM, editors. Micronutrients in Agriculture. Madison Wisconsin USA: Soil Science Society of America; 1991. p. 145-86.

31. Cesco S, Römheld V, Varanini Z, Pinton R. Solubilization of iron by waterextractable humic substances. J Plant Nutr Soil Sci. 2000;163(3):285-90.

32. Hopkins BG, Jolley VD, Brown JC. Plant utilization of iron solubilized by oat phytosiderophores. J Plant Nutr. 1992;15(10):1599-612.

33. Jolley VD, Brown JC. Genetically controlled uptake and use of iron by plants. In: Manthey JA, Crowley DE, Luster DG, editors. Biochemistry of micronutrient in the rhizosphere. Boca Raton: LA, CRC Press; 1994. p. 251-66.

34. Zuo Y, Zhang F. Iron and zinc biofortication strategies in dicot plants by intercropping with gramineous species. Agron Sustain Dev. 2009;29:63-71.

35. Xiong H, Kakei Y, Kobayashi T, Guo X, Nakazono M, Takahashi H, et al. Molecular evidence for phytosiderophore-induced improvement of iron nutrition of peanut intercropped with maize in calcareous soil. Plant Cell Environ. 2013:36(10):1888-902.

36. Pinton R, Cesco S, Santi S, Agnolon F, Varanini Z. Water-extractable humic substances enhance iron deficiency responses by Fe-deficient cucumber plants. Plant Soil. 1999;210(2):145-57. 
37. Zanin L, Tomasi N, Rizzardo C, Gottardi S, Terzano R, Alfeld M, et al. Iron allocation in leaves of Fe-deficient cucumber plants fed with natural Fe complexes. Physiol Plant. 2015;154(1):82-94.

38. Broadley M, Brown P, Cakmak I, Rengel Z, Zhao F. Functions of nutrients: micronutrients. In: Marschner P, editor. Marschner's Mineral Nutrition of Higher Plants. London UK: Academic; 2012. p. 190-248.

39. Smyth GK. Linear models and empirical Bayes methods for assessing differential expression in microarray experiments. Stat Appl Genetics Mol Biol. 2004;3:article 3.

40. Samira R, Stallmann A, Massenburg LN, Long TA. Ironing out the issues: integrated approaches to understanding iron homeostasis in plants. Plant Sci. 2013;210:250-9.

41. Gene Ontology Consortium. http://www.geneontology.org. Accessed Jan 52016.

42. UniProt. http://www.uniprot.org. Accessed Jan 52016.

43. Badri DV, Vivanco JM. Regulation and function of root exudates. Plant Cell Environ. 2009;32(6):666-81.

44. Rose JKC, Lee HH, Bennett AB. Expression of a divergent expansin gene is fruit-specific and ripening-regulated. Proc Natl Acad Sci U S A. 1997; 94(11):5955-60.

45. Franková L, Fry SC. Biochemistry and physiological roles of enzymes that 'cut and paste' plant cell-wall polysaccharides. J Exp Bot. 2013;64(12):3519-50.

46. Mølhøj M, Verma R, Reiter WD. The biosynthesis of the branched-chain sugar D-apiose in plants: functional cloning and characterization of a UDP-D-apiose/ UDP-D-xylose synthase from Arabidopsis. Plant J. 2003;35(6):693-703.

47. Gu X, Glushka J, Yin Y, Xu Y, Denny T, Smith J, et al. Identification of a bifunctional UDP-4-keto-pentose/UDP-xylose synthase in the plant pathogenic bacterium Ralstonia solanacearum strain GMl1000, a distinct member of the 4,6-dehydratase and decarboxylase family. J Biol Chem. 2010;285(12):2030-40.

48. Martínez-Cuenca MR, Iglesias DJ, Talón M, Abadía J, López-Millán AF, Primo-

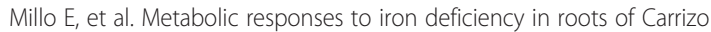
citrange [Citrus sinensis (L.) Osbeck. $\times$ Poncirus trifoliata (L.) Raf.]. Tree Physiol. 2013:33(3):320-9.

49. Vigani G, Maffi D, Zocchi G. Iron availability affects the function of mitochondria in cucumber roots. New Phytol. 2009;182(1):127-36.

50. Vigani $G$, Zocchi $G$. The fate and the role of mitochondria in Fe-deficient roots of strategy I plants. Plant Signal Behav. 2009;4(5):375-9.

51. Owen OE, Kalhan SC, Hanson RW. The key role of anaplerosis and cataplerosis for citric acid cycle function. J Biol Chem. 2002;277(34):30409-12.

52. Pontiggia A, De Nisi P, Zocchi G. Effect of iron deficiency on RNA and protein synthesis in cucumber roots. J Plant Nutr. 2003;26(10-11):2177-86.

53. Van Aken O, Whelan J, Van Breusegem F. Prohibitins: mitochondrial partners in development and stress response. Trends Plant Sci. 2010;15(2):275-82

54. Bell PF, McLaughlin MJ, Cozens G, Stevens DP, Owens G, South H. Plant uptake of ${ }^{14} \mathrm{C}$-EDTA, ${ }^{14} \mathrm{C}$-Citrate, and ${ }^{14} \mathrm{C}$-Histidine from chelator-buffered and conventional hydroponic solution. Plant Soil. 2003;253(2):311-9.

55. Borlotti A, Vigani G, Zocchi G. Iron deficiency affects nitrogen metabolism in cucum- ber (Cucumis sativus L.) plants. BMC Plant Biol. 2012;12:189.

56. Yang Q, Wang Y, Zhang J, Shi W, Qian C, Peng X. Identification of aluminumresponsive proteins in rice roots by a proteomic approach: cysteine synthase as a key player in Al response. Proteomics. 2007;7(5):737-49.

57. Ricachenevsky FK, Sperotto RA, Menguer PK, Fett JP. Identification of Feexcess-induced genes in rice shoots reveals a WRKY transcription factor responsive to Fe, drought and senescence. Mol Biol Rep. 2010;37(8):3735-45.

58. Sun X, Jones WT, Rikkerink EH. GRAS proteins: the versatile roles of intrinsically disordered proteins in plant signalling. Biochem J. 2012;442(1):1-12.

59. Mayrose M, Ekengren SK, Melech-Bonfil S, Martin GB, Sessa G. A novel link between tomato GRAS genes, plant disease resistance and mechanical stress response. Mol Plant Pathol. 2006;7(6):593-604.

60. Nakamura Y, Ohta H. Phosphatidic Acid Phosphatases in Seed Plants. In: Munnik T, editor. Lipid Signaling in Plants. Berlin Heidelberg: Springer; 2010. p. 131-41.

61. Ruelland E, Kravetsb V, Derevyanchukb M, Martinecc J, Zachowskia A, Pokotylob I. Role of phospholipid signalling in plant environmental responses. Environ Exp Bot. 2015;114:129-43.

62. Zhao J, Wang C, Bedair M, Welti R, Sumner LW, Baxter I, et al. Suppression of phospholipase D s confers increased aluminum resistance in Arabidopsis thaliana. PLoS ONE. 2011;6(12):e28086.
63. Zou L, Li H, Ouyang B, Zhang J, Ye Z. Cloning and mapping of genes involved in tomato ascorbic acid biosynthesis and metabolism. Plant Sci. 2006;170(1):120-7.

64. Pinton R, Cesco S, De Nobili M, Santi S, Varanini Z. Water- and pyrophosphate-extractable humic substances fractions as a source of iron for Fe-deficient cucumber plants. Biol Fert Soils. 1997;26(1):23-7.

65. von Wirén N, Mori S, Marschner H, Römheld V. Iron inefficiency in maize mutant ys1 (Zea mays L. CV Yellow-Stripe) is caused by a defect in uptake of iron phytosiderophores. Plant Physiol. 1994;106(1):71-7.

66. Cesco S, Nikolic M, Römheld V, Varanini Z, Pinton R. Uptake of ${ }^{59} \mathrm{Fe}$ from soluble ${ }^{59} \mathrm{Fe}$-humate complexes by cucumber and barley plants. Plant Soil. 2002;241(1):121-8

67. Bienfait HF, van den Briel W, Mesland-Mul NT. Frees pace iron pools in roots: generation and mobilization. Plant Physiol. 1985;78(3):596-600.

68. CombiMatrix | Clinical Laboratory Irvine CA. http://www.combimatrix.com. Accessed Jan 52016.

69. Functional Genomics Lab. http://ddlab.sci.univr.it/FunctionalGenomics. Accessed Jan 52016.

70. Rouillard JM, Zuker M, Gulari E. OligoArray 2.0: design of oligonucleotide probes for DNA microarrays using a thermodynamic approach. Nucleic Acid Res. 2003;31(12):3057-62.

71. DFCl Tomato Gene Index. http://compbio.dfci.harvard.edu/tgi. Accessed Jan 5 2016..

72. Gene Expression Omnibus. http://www.ncbi.nlm.nih.gov/geo. Accessed Jan 52016.

73. Gentleman RC, Carey VJ, Bates DM, Bolstad B, Dettling M, Dudoit S, et al. Bioconductor: open software development for computational biology and bioinformatics. Genome Biol. 2004;5(10):R80.

74. Bioconductor. http://www.bioconductor.org. Accessed Jan 52016.

75. Ihaka R, Gentleman R. R: A language for data analysis and graphics. J Comput Graph Stat. 1996:5(3):299-314.

76. R: The R Project for Statistical Computing. http://www.r-project.org. Accessed Jan 52016.

77. Altschul SF, Madden TL, Schäffer AA, Zhang J, Zhang Z, Miller W, et al. Gapped BLAST and PSI-BLAST: a new generation of protein database search programs. Nucleic Acid Res. 1997;25(17):3389-402.

78. Ritz C, Spiess AN. qpcR: an R package for sigmoidal model selection in quantitative realtime polymerase chain reaction analysis. Bioinformatics. 2008;24(13):1549-55.

79. GO Terms Classifications Counter. http://i.animalgenome.org/bioinfo/tools/ catego. Accessed Jan 52016.

\section{Submit your next manuscript to BioMed Central and we will help you at every step:}

- We accept pre-submission inquiries

- Our selector tool helps you to find the most relevant journal

- We provide round the clock customer support

- Convenient online submission

- Thorough peer review

- Inclusion in PubMed and all major indexing services

- Maximum visibility for your research

Submit your manuscript at www.biomedcentral.com/submit

) Biomed Central 